\title{
Parastagonospora nodorum and Related Species in Western Canada: Genetic Variability and Effector Genes
}

\author{
Mohamed Hafez, ${ }^{1,2}$ Ryan Gourlie, ${ }^{1}$ Therese Despins, ${ }^{1}$ Thomas K. Turkington, ${ }^{3}$ Timothy L. Friesen, ${ }^{4}$ and \\ Reem Aboukhaddour ${ }^{1, \dagger}$ \\ ${ }^{1}$ Agriculture and Agri-Food Canada, Lethbridge Research and Development Center, Lethbridge, Alberta, Canada (working address) \\ 2 Department of Botany and Microbiology, Faculty of Science, Suez University, Suez, Egypt (permanent address) \\ ${ }^{3}$ Agriculture and Agri-Food Canada, Lacombe Research and Development Center, Lacombe, Alberta, Canada \\ ${ }^{4}$ U.S. Department of Agriculture, Agricultural Research Service, Edward T. Schafer Agricultural Research Center, Fargo, ND, U.S.A. \\ Accepted for publication 9 July 2020.
}

\begin{abstract}
Parastagonospora nodorum is an important fungal pathogen that causes Septoria nodorum blotch (SNB) in wheat. This pathogen produces several necrotrophic effectors that act as virulence factors; three have been cloned, SnToxA, SnTox1, and SnTox3. In this study, P. nodorum and its sister species $P$. avenaria f. tritici (Pat1) were isolated from wheat node and grain samples collected from distanced sites in western Canada during 2018. The presence of effector genes and associated haplotypes were determined by PCR and sequence analysis. An internal transcribed spacer-restriction fragment length polymorphism test was developed to distinguish between leaf spotting pathogens (P. nodorum, Pat1, Pyrenophora tritici-repentis, and Bipolaris sorokiniana). P. nodorum was mainly recovered from wheat nodes and to a lesser extent from the grains, while Pat1 was exclusively isolated from grain samples. The effector genes were present in almost all $P$. nodorum isolates, with the ToxA haplotype 5 (H5) being most prevalent, while a novel ToxA haplotype (denoted here H21) is
\end{abstract}

ABSTRACT reported for the first time. In Pat1, only combinations of SnToxl and SnTox3 genes were present. A ToxA haplotype network was also constructed to assess the evolutionary relationship among globally found haplotypes to date. Finally, cultivars representing wheat development in Canada for the last century were tested for sensitivity to Sn-effectors and to the presence of $T s n 1$, the ToxA sensitivity gene. Of tested cultivars, 32.9 and $56.9 \%$ were sensitive to SnTox 1 and SnTox3, respectively, and Tsn1 was present in 59\% of the cultivars. In conclusion, P. nodorum and Pat1 were prevalent wheat pathogens in Canada with a potential tissuespecific colonization capacity, while producing necrotrophic effectors to which wheat is sensitive.

Keywords: disease control and pest management, haplotypes, host selective toxins, necrotrophic effectors, population biology, SNB, Tsnl, ToxA, SnTox1, SnTox3
Parastagonospora nodorum (teleomorph: Phaeosphaeria nodorum), previously known as Septoria nodorum and Stagonospora nodorum (teleomorph: Leptosphaeria nodorum), is a necrotrophic ascomycete fungal pathogen causing Septoria nodorum blotch (SNB) on bread (Triticum aestivum) and durum (Triticum turgidum) wheat. P. avenaria f. tritici, previously known as Leptosphaeria avenaria $\mathrm{f}$. triticea, was first described from wheat and other cereals in Canada (Johnson 1947; Shaw 1957a, b). P. nodorum is one of three main Parastagonospora (Phaeosphaeria)-like species infecting cereals that were identified based on morphological characteristic and host specialization (reviewed in Shipton et al. 1971): (i) $P$. nodorum infects wheat; (ii) $P$. avenaria infects oat; and (iii) group within $P$. avenaria are nonpathogenic on oat, but infect wheat and barley, and therefore are named P. avenaria f. tritici (Pat) (Johnson 1947; Shaw $1957 \mathrm{a}$, b). Within $P$. avenaria f. tritici, three genetically

${ }^{\dagger}$ Corresponding author: R. Aboukhaddour; reem.aboukhaddour@canada.ca

Funding: Financial support was provided by Agriculture and Agri-Food Canada (AAFC), and the Wheat Funding Consortium to R. Aboukhaddour's Lab at AAFCLethbridge. The funding for the experimental sites at the four AAFC locations to K. Turkington's lab was provided as part of the Canadian Agricultural Partnership, Canadian Wheat Research Coalition, Alberta Wheat Commission, Saskatchewan Wheat Development Commission, Manitoba Wheat and Barley Growers Association, and the Western Grains Research Foundation.

*The $\boldsymbol{e}$-Xtra logo stands for "electronic extra" and indicates supplementary figures and supplementary tables are published online.

The author(s) declare no conflict of interest.

(C) Her Majesty the Queen in Right of Canada as represented by the Minister of Agriculture and Agri-Food, 2020 distinct groups, Pat1, Pat2, and Pat 3 have been differentiated based on variation in the internal transcribed spacer (ITS) sequence (Ueng and Chen 1994; Ueng et al. 1992, 1995). The homothallic Patl is exclusively present in wheat grains, and along with $P$. nodorum are important pathogens in the SNB complex in North America and worldwide (McDonald et al. 2012). Symptoms of SNB on leaves appear as necrotic leaf blotches and on spikes as discoloration of glume tissues, a symptom known as glume blotch. High yield losses due to SNB are associated with reduced kernel number, size, and quality. Unlike other foliar pathogens, $P$. nodorum infects the seed directly, reducing seed germination rates and causing lesioned coleoptiles and damping off under heavy infection (Bennett et al. 2007; Shah et al. 1995).

Significant losses were first associated with $P$. nodorum outbreaks in the United States and Canada during the 1920s and 1940s (Shipton et al. 1971). Since then, P. nodorum has maintained a continuous presence, and today SNB is recognized as a major wheat disease in North America, Australia, and other parts of the world, causing up to $30 \%$ yield loss (Solomon et al. 2006). The $P$. nodorum-wheat interaction has been used as a research model for the last 20 years, and has tremendously advanced our knowledge on necrotrophic pathogenicity in fungi. Tan spot of wheat which is caused by Pyrenophora tritici-repentis along with SNB, are recognized as the main wheat diseases in western Canada followed by spot blotch, which is caused by Bipolaris sorokiniana (Fernandez et al. 2016). Depending on soil type, agricultural practices, geographical region, and other environmental factors, the prevalence of these pathogenic species may vary. For example, in the province of Saskatchewan, $P$. nodorum is the most prevalent pathogen in the black soil zones (Fernandez et al. 2016). In 2018, $P$. nodorum prevalence (percentage of fields from which the 
TABLE 1. Reaction of Canadian wheat cultivars to SnTox1, SnTox3, and Pyrenophora tritici-repentis ToxA, and the PCR screening for Tsn1

\begin{tabular}{|c|c|c|c|c|c|c|}
\hline Cultivar & $\operatorname{Hos}^{\mathrm{a}}$ & Release year & SnTox $1^{b}$ & SnTox $3^{b}$ & $\operatorname{Tox}^{\mathrm{c}}$ & $T s n 1^{\mathrm{d}}$ \\
\hline $5500 \mathrm{HR}$ & BW & 2000 & 0 & 2 & $\mathrm{~S}$ & + \\
\hline $5600 \mathrm{HR}$ & BW & 1999 & 1 & 2 & I & - \\
\hline $5601 \mathrm{HR}$ & BW & 2001 & 0 & 0 & $\mathrm{~S}$ & + \\
\hline $5602 \mathrm{HR}$ & $\mathrm{BW}$ & 2004 & 0 & 0 & $\mathrm{~S}$ & + \\
\hline $5603 \mathrm{HR}$ & BW & 2008 & 0 & 0 & I & - \\
\hline 5700PR & BW & 2000 & 1 & 2 & I & - \\
\hline 5701PR & BW & 2001 & 0 & 1 & I & - \\
\hline $5702 \mathrm{PR}$ & BW & 2007 & 0 & 0 & $\mathrm{~S}$ & + \\
\hline AC Abbey & BW & 1998 & 0 & 0 & I & NA \\
\hline AC Avonlea & DW & 1997 & 0 & 2 & I & - \\
\hline AC Barrie & BW & 1994 & 0 & 2 & I & - \\
\hline AC Cadillac & BW & 1996 & 0 & 1 & I & - \\
\hline AC Carberry & BW & 2009 & 1 & 0 & $\mathrm{~S}$ & NA \\
\hline AC Crystal & BW & 1996 & 0 & 2 & I & - \\
\hline AC Elsa & BW & 1996 & 0 & 1 & I & - \\
\hline AC Foremost & BW & 1994 & 0 & 2 & I & - \\
\hline AC Harvest & BW & 2001 & 0 & 0 & $\mathrm{~S}$ & + \\
\hline AC Intrepid & BW & 1997 & 0 & 1 & S & + \\
\hline AC Laura & BW & 1986 & 0 & 2 & I & NA \\
\hline AC Lillian & BW & 2003 & 0 & 0 & I & - \\
\hline AC Lovitt & BW & 2002 & 0 & 0 & S & + \\
\hline AC Morse & DW & 1996 & 0 & 0 & S & + \\
\hline AC Napoleon & DW & 1999 & 0 & 2 & S & + \\
\hline AC Navigator & DW & 1999 & 2 & 0 & S & + \\
\hline AC Reed & BW & 1991 & 1 & 0 & S & NA \\
\hline AC Splendor & BW & 1996 & 0 & 2 & I & - \\
\hline AC Superb & BW & 2000 & 1 & 0 & S & + \\
\hline AC Taber & BW & 1991 & 2 & 2 & I & - \\
\hline AC Vista & BW & 1996 & 1 & 2 & $\mathrm{~S}^{*}$ & NA \\
\hline Alvena & BW & 2006 & 0 & 2 & $\mathrm{~S}$ & NA \\
\hline Brigade & BW & 2008 & 2 & 0 & I & - \\
\hline Burnside & $\mathrm{BW}$ & 2003 & 0 & 0 & S & + \\
\hline CDC Abound & BW & 2006 & 1 & 0 & $S$ & NA \\
\hline CDC Alsask & BW & 2004 & 0 & 2 & I & - \\
\hline CDC Bounty & $\mathrm{BW}$ & 1999 & 0 & 0 & S & + \\
\hline CDC Go & BW & 2003 & 0 & 1 & S & + \\
\hline CDC Imagine & BW & 2002 & 0 & 0 & S & + \\
\hline CDC Merlin & BW & 1992 & 1 & 2 & I & - \\
\hline CDC Osler & BW & 2003 & 0 & 0 & $\mathrm{~S}^{*}$ & NA \\
\hline CDC Rama & BW & 2001 & 1 & 0 & $\mathrm{~S}$ & + \\
\hline CDC Teal & $\mathrm{BW}$ & 1991 & 0 & 2 & S & + \\
\hline CDC Thrive & BW & 2009 & 0 & 0 & S & + \\
\hline CDC Verona & DW & 2008 & 0 & 0 & S & + \\
\hline CDC Walrus & BW & 2003 & 0 & 0 & $\mathrm{~S}$ & + \\
\hline CDN Bison & BW & 2008 & 0 & 0 & I & - \\
\hline Columbus & BW & 1980 & 1 & 1 & $\mathrm{~S}^{*}$ & + \\
\hline Commander & DW & 2004 & 2 & 2 & $\mathrm{~S}^{*}$ & + \\
\hline Eatonia & BW & 1993 & 0 & 0 & I & - \\
\hline Enterprise & DW & 2009 & 1 & 0 & $\mathrm{~S}$ & + \\
\hline Eurostar & BW & 2008 & 0 & 0 & I & - \\
\hline Fieldstar VB & BW & 2007 & 1 & 1 & S & NA \\
\hline Glencross VB & BW & 2007 & 0 & 0 & $\mathrm{~S}$ & NA \\
\hline Glenlea & BW & 1972 & 0 & 0 & $\mathrm{~S}$ & + \\
\hline Glenn & BW & 2009 & 0 & 1 & $\mathrm{~S}$ & NA \\
\hline Goodeve VB & BW & 2007 & 0 & 2 & $\mathrm{~S}$ & NA \\
\hline Helios & BW & 2005 & 1 & 2 & I & NA \\
\hline HY682 & BW & 2009 & 0 & 0 & I & - \\
\hline HY985 & BW & 2010 & 0 & 0 & I & - \\
\hline Infinity & BW & 2004 & 2 & 2 & I & - \\
\hline Journey & BW & 2001 & 2 & $\mathrm{~S}$ & $\mathrm{~S}$ & NA \\
\hline Kane & BW & 2006 & 2 & 2 & $\mathrm{~S}$ & NA \\
\hline Katepwa & BW & 1981 & 2 & 1 & $\mathrm{~S}$ & + \\
\hline Kyle & BW & 1984 & 2 & 2 & $\mathrm{~S}$ & + \\
\hline
\end{tabular}

a The host bread wheat (BW) or durum wheat (DW).

b The reaction of wheat cultivars to SnTox1 and SnTox3, rated for symptom development on the second leaf as follows: $0=$ no symptoms; $1=$ visible symptoms; and 2 = strong symptoms (clear chlorosis by SnTox 1 and extensive necrosis by SnTox3).

c Reactions to Pyrenophora tritici-repentis ToxA, summarized from previous work by Lamari et al. (2005) and Tran et al. (2017) were as follows: S, sensitive; I, insensitive; and $\mathrm{S}^{*}$, heterogeneous reaction, where some plants were sensitive and others were insensitive.

d The Tsn1 amplicon: +, present; -, absent; and NA, not tested.
TABLE 1. (Continued)

\begin{tabular}{lcccccc}
\hline Cultivar & Host $^{\mathrm{a}}$ & Release year & SnTox1 $^{\mathrm{b}}$ & SnTox3 $^{\mathrm{b}}$ & ToxA $^{\mathrm{c}}$ & Tsn $^{\mathrm{d}}$ \\
\hline Marquis & BW & 1911 & 1 & 1 & $\mathrm{~S}$ & + \\
McKenzie & BW & 1997 & 0 & 2 & $\mathrm{~S}$ & + \\
Neepawa & BW & 1969 & 0 & 1 & $\mathrm{~S}$ & + \\
Prodigy & BW & 1998 & 0 & 0 & $\mathrm{~S}$ & + \\
PT559 & BW & 2003 & 0 & $\mathrm{~S}$ & $\mathrm{~S}$ & + \\
Red Fife & BW & 1870 & 1 & 2 & $\mathrm{~S}$ & + \\
Roblin & BW & 1986 & 0 & 1 & $\mathrm{I}$ & - \\
Sadash & BW & 2006 & 0 & 2 & S & NA \\
Snowbird & BW & 2004 & 0 & 2 & S & + \\
Snowstar & BW & 2009 & 2 & 2 & S & NA \\
Somerset & BW & 2004 & 0 & 2 & S & NA \\
Stettler & BW & 2008 & 1 & 0 & S & + \\
Strongfield & DW & 2003 & 2 & 0 & S & + \\
Thatcher & BW & 1935 & 0 & 1 & I & - \\
Transcend & DW & 2010 & 0 & 1 & I & - \\
Unity VB & BW & 2007 & 0 & 2 & S & + \\
\hline
\end{tabular}

pathogen was isolated) and incidence (percentage of total pathogen isolations) in the prairies (Manitoba, Saskatchewan, and Alberta) ranged from 28 to $58 \%$ and 6 to $30 \%$, respectively (Boots et al. 2019; Chang et al. 2019; Henriquez et al. 2019).

$P$. nodorum, Pyrenophora tritici-repentis, and other related species within the leaf spot complex are known for their ability to secrete several necrotrophic effectors (NEs), previously known as host-selective toxins (HSTs), which are often proteins that act as virulence factors and mediate disease development through an inverse gene-for-gene interaction (Friesen et al. 2007). To date, nine NE-host gene interactions have been identified in P. nodorum along with their corresponding sensitivity genes in wheat $(\mathrm{Snn})$, and these are listed here as (pathogen effector-host sensitivity gene): SnToxA-Tsn1; SnTox1-Snn1; SnTox2-Snn2; SnTox3-Snn3-B1; SnTox3-Snn3-D1; SnTox4-Snn4; SnTox5-Snn5; SnTox6-Snn6; and SnTox7-Snn7 (reviewed in Duba et al. 2018). Only three P. nodorum effector genes have been cloned, SnToxA, SnToxl, and SnTox3. SnToxA is a protein identical to Pyrenophora triticirepentis ToxA, the most studied NE and its coding gene was cloned first in Pyrenophora tritici-repentis (Ballance et al. 1996; Ciuffetti et al. 1997). Pyrenophora tritici-repentis ToxA is the only identified necrosis causing effector in Pyrenophora tritici-repentis and was the first proteinaceous host-specific NE to be identified in a fungal species; it is encoded by the single copy gene ToxA, and the effector alone causes extensive necrosis only to sensitive wheat genotypes carrying the toxin sensitivity gene Tsn1 (Faris et al. 2013). The ToxA gene is present in both Pyrenophora tritici-repentis and $P$. nodorum and shares $99.7 \%$ sequence identity in both species (Friesen et al. 2006). Subsequently, ToxA homologs were found in other plant pathogenic fungi including the wheat glume blotch pathogen Pat1, the spot blotch pathogen $B$. sorokiniana, and the maize pathogen Cochliobolus heterostrophus (Lu et al. 2015; McDonald et al. 2018; Navathe et al.2020). ToxA is one of the clearest examples of a fungal gene being horizontally transferred between different species. $P$. nodorum is hypothesized to be the donor of ToxA to Pyrenophora tritici-repentis based on the higher level of sequence diversity found in P. nodorum isolates from around the world (Friesen et al. 2006; Ghaderi et al. 2020).

SnTox 1 was the first identified NE unique to $P$. nodorum and causes necrosis in susceptible wheat genotypes carrying the Snn1 sensitivity gene (Liu et al. 2004a, b; Reddy et al. 2008). The SnToxl gene is present in about $85 \%$ of a global collections of P. nodorum isolates (Liu et al. 2012; McDonald et al. 2013). In total, 22 SnToxl haplotypes have been identified in $P$. nodorum, suggesting strong diversifying selection pressure on this gene (Ghaderi et al. 2020; Liu et al. 2012; McDonald et al. 2013; Richards et al. 2019). A monomorphic SnToxl (haplotype 4) was recently found in $24 \%$ of the isolates ( 37 out of 152 isolates) of the wheat glume blotch pathogen Patl from the United States, 
Canada, and Iran (McDonald et al. 2013). Unlike SnToxA and SnTox1, SnTox3 interacts with two homologous genes (Snn3-B1 and $S n n 3-D 1$ ) on wheat chromosomes 5B and 5D, respectively, to develop disease symptoms (Zhang et al. 2011). However, the SnTox3-Snn3-D1 interaction can induce more severe necrosis on susceptible wheat lines than the SnTox3-Snn3-B1 interaction (Zhang et al. 2011).

In this study, $P$. nodorum and its sister species Patl and their associated effector genes in western Canada were investigated. The frequencies of SnToxA, SnTox1, and SnTox3 and the associated haplotypes were analyzed and used with previously published/ released haplotypes to establish an updated ToxA haplotype network. Additionally, a molecular diagnostic tool to enable the distinction between the four main leaf spot pathogenic species: P. nodorum, Pat1, Pyrenophora tritici-repentis, and B. sorokiniana, associated with the leaf spot complex on wheat was optimized and validated. Finally, sensitivity to SnTox 1 and SnTox 3 was assessed in Canadian wheat cultivars representing over a century of wheat development in Canada. These cultivars were also screened for the presence of Tsn1, the ToxA sensitivity gene.

\section{MATERIALS AND METHODS}

Fungal cultures. Wheat node and grain samples were collected during the 2018 growing season from one experimental site at Agriculture and Agri-Food Canada (AAFC), Scott Saskatchewan, and three AAFC experimental sites representing southern, central, and northern Alberta, at Lethbridge, Lacombe, and Beaverlodge, respectively. Three lower stem pieces (node with 1-cm segments on both sides) and five wheat grains were randomly selected from each sample set. Selections were surface sterilized with $2 \%$ sodium hypochlorite for $3 \mathrm{~min}$ and then rinsed twice in sterile distilled water. Samples were plated on 9-cm-diameter plates with potato dextrose agar (PDA: Difco Laboratories, Franklin Lakes, NJ) supplemented with neomycin sulfate $(0.12 \mathrm{~g} /$ liters $)$ and streptomycin sulfate $(1 \mathrm{~g} /$ liter $)$ and incubated at room temperature for 7 to 10 days. P. nodorum and Patl isolates were identified, based on morphological colony characteristics, and were transferred onto V8-PDA plates ( $150 \mathrm{ml}$ of V8 juice, $10 \mathrm{~g}$ of PDA, $3 \mathrm{~g}$ of $\mathrm{CaCO}_{3}, 10 \mathrm{~g}$ of agar, and 1 liter of distilled $\mathrm{H}_{2} \mathrm{O}$ ) to induce sporulation. During sporulation, a single pycnidium was isolated and transferred with a sterile needle to the center of a fresh V8-PDA plate. Species identity for a subset of 26 Phaeosphaeria isolates was confirmed by sequencing the ITS region, beta-tubulin $(\beta-t u b)$, and the actin genes, and used for the molecular experiments.

DNA extraction and PCR amplifications. A total of 26 isolates (18 P. nodorum and 8 Pat 1) from the four locations (AAFC Beaverlodge, Lacombe, Lethbridge, and Scott) were recovered from wheat node and grain samples and were selected for molecular characterization. Two Pyrenophora tritici-repentis isolates (G4057 and S115-1) and two B. sorokiniana isolates (C404-11 and C10913) were also included in the molecular characterization to develop a PCR-restriction fragment length polymorphism (RFLP) tool (as described below). The Pyrenophora tritici-repentis and B. sorokiniana isolates were previously isolated and identified in our lab from wheat node and grain samples, respectively. Agar plugs from the margins of actively growing mycelia on PDA plates ( $\sim 6$ days old) were used to inoculate $50 \mathrm{ml}$ of $1 / 4$-strength potato dextrose broth (PDB) medium and incubated at room temperature with no shaking for 7 days. Fungal mats were collected, freeze-dried, and stored at $-20^{\circ} \mathrm{C}$ until ground into powder using liquid nitrogen. Genomic DNA (gDNA) was extracted using the DNeasy plant mini kit (Qiagen) following the manufacturer's instructions. DNA was also extracted from healthy leaf tissue of 61 wheat genotypes (Table 1) for the detection of Tsn1 using the DNeasy plant mini kit (Qiagen) following the manufacturer's instructions.

PCR reactions were performed in a final volume of $50 \mu \mathrm{l}$ using the Taq PCR core kit (Qiagen) with the following reagent concentrations: CoralLoad PCR buffer (1x), dNTP mixture (200 $\mu \mathrm{M}$ each), forward and reverse primers $(0.2 \mu \mathrm{M}$ each), Taq DNA polymerase $(1.25 \mathrm{U} / 50 \mu \mathrm{l}), \sim 10: 50 \mathrm{ng}$ of gDNA template, and the total volume of the PCR reaction was adjusted to $50 \mu \mathrm{l}$ with nuclease-free $\mathrm{H}_{2} \mathrm{O}$. The ITS region was amplified by PCR using the fungal oligonucleotide primers BMB-CR and ITS-4B (White et al. 1990). The PCR conditions were as follows: initial denaturation at $94^{\circ} \mathrm{C}$ for $3 \mathrm{~min}$, followed by 30 cycles of $94^{\circ} \mathrm{C}$ for $30 \mathrm{~s}, 55^{\circ} \mathrm{C}$ for 30 $\mathrm{s}$, and $72^{\circ} \mathrm{C}$ for $1 \mathrm{~min}$, and a final extension step at $72^{\circ} \mathrm{C}$ for $5 \mathrm{~min}$. The $\beta-t u b$ gene was amplified using the primer pair T1/T22 (O'Donnell and Cigelnik 1997). The thermal cycler conditions for $\beta$-tub gene amplification were as follows: an initial denaturation at $94^{\circ} \mathrm{C}$ for $3 \mathrm{~min}$, followed by 35 cycles of $94^{\circ} \mathrm{C}$ for $35 \mathrm{~s}, 52^{\circ} \mathrm{C}$ for 55 $\mathrm{s}$, and $72^{\circ} \mathrm{C}$ for $2 \mathrm{~min}$, and a final extension step at $72^{\circ} \mathrm{C}$ for $5 \mathrm{~min}$. A short fragment ( $\sim 270 \mathrm{bp}$ ) from the actin gene was amplified using the primers SnActinF and SnActinR as described in Gao et al. (2015). The SnActinF/R-PCR fragment was sequenced and the sequence data used to retrieve similar actin sequences from GenBank (E-value 4e-120) to design primers that amplify the whole actin gene. Two reference actin sequences ( $P$. nodorum XM_ 001791742; Pyrenophora tritici-repentis JX129892) were used to design the Act-F2 and Act-R2 primers. The Act-F2/R2 primer pair were used to amplify 843-bp fragment for sequencing. The PCR conditions were as follows: initial denaturation at $94^{\circ} \mathrm{C}$ for $3 \mathrm{~min}$, followed by 35 cycles of $94^{\circ} \mathrm{C}$ for $1 \mathrm{~min}, 55^{\circ} \mathrm{C}$ for $1 \mathrm{~min}$, and $72^{\circ} \mathrm{C}$ for $1 \mathrm{~min}$, and a final extension step at $72^{\circ} \mathrm{C}$ for $10 \mathrm{~min}$.

PCR screening for the presence of SnToxl and SnTox3 were done according to Gao et al. (2015) using the primer pairs SnTox1-cF/ SnTox1-cR and SnTox3-cF/SnTox3-cR, respectively. SnToxA was detected by PCR using the ToxA open reading frame (ORF)-binding primers TA51F and TA52R (Andrie et al. 2007). The primer pair ToxA192/ToxA1155 (Aboukhaddour et al. 2013) was used to amplify the ToxA gene with the flanking upstream and downstream regions (964 bp) for sequencing. PCR to detect the presence of Tsn 1 was done using specific primers LRR.F2300 and LRR.R3900 that anneal to the leucine-rich repeat (LRR) domain (Faris et al. 2010). Details about the primers used during the current study are in Table 2.

All PCR amplicons were analyzed by gel electrophoresis through 1 to $2 \%$ agarose gels in $1 \times$ TBE buffer $(89 \mathrm{mM}$ Tris-borate, $10 \mathrm{mM}$ EDTA, pH 8.0). Sizes of the PCR amplicons were estimated against a 1-kb plus DNA ladder (Thermo Fisher Scientific, ON, Canada) and visualized under UV light after staining with RedSafe (iNtRON Biotechnology Inc., South Korea). PCR amplicons were purified and sequenced in two directions by Psomagen Inc. (Rockville, MD, U.S.A.).

Sequence analysis. The initial nucleotide sequence alignments were done with Clustal-X v2 (Thompson et al. 1997) and the resulting alignments were refined with GeneDoc v2.5.010 (Nicholas 1997). BLAST searches (Altschul et al. 1990) on GenBank were done to confirm species identity for all fungal isolates (E-value 0). Programs within PHYLIP package v3.6 (Felsenstein 2005) were used for phylogenetic analysis, DNADIST was used to generate distance matrices using concatenated ITS, $\beta$-tub, and actin alignments for each fungal isolate. Distance matrices were used by the NEIGHBOR program to generate neighbor-joining $(\mathrm{NJ})$ trees. In order to evaluate node support values observed in the NJ analysis, the SEQBOOT program was used to generate 1,000 bootstrap (BS) replicates and a majority rule consensus tree was constructed with the CONSENSE program and visualized using iTOL v3 (Letunic and Bork 2016). GenBank accession numbers for all sequences used in phylogenetic analysis are listed in Supplementary Table S1.

ToxA haplotype network. To determine the ToxA haplotype(s) in P. nodorum and Patl isolates, ToxA coding sequences generated during the current study (18 sequences) were aligned with the previously published ToxA haplotypes from $P$. nodorum (Friesen et al. 2006; Ghaderi et al. 2020; McDonald et al. 2013; Stukenbrock and McDonald 2007), Pyrenophora tritici-repentis (Ballance et al. 
1996; Ciuffetti et al. 1997; Friesen et al. 2006), B. sorokiniana (McDonald et al. 2018), and Patl (McDonald et al. 2018). ToxA coding sequences were aligned with Clustal-X v2 and the generated alignment nexus file was used in PopART v. 1.7 (http:// popart.otago.ac.nz; Leigh and Bryant 2015) to generate a ToxA haplotype network. The method from Templeton et al. (1992) (Templeton, Crandall, and Sing [TCS]) was used in PopART to build a TCA haplotype network. The generated TCS network was then edited and visualized by CorelDraw x 4 Graphic. Synonymous/ nonsynonymous polymorphism was calculated with DnaSP v. 5.10 (Librado and Rozas 2009) to test for neutral selection. ToxA and $\beta$-tub sequences from $P$. nodorum recovered during the current study (18 sequences for each gene) were analyzed with DnaSP to calculate the $\mathrm{pN} / \mathrm{pS}$ ratio (relative abundance of nonsynonymous and synonymous polymorphisms $)$. The $\mathrm{pN} / \mathrm{pS}=(\pi \mathrm{N} / \mathrm{LN}) /(\pi \mathrm{S} / \mathrm{LS})$, where $\pi \mathrm{N}$ and $\pi \mathrm{S}$ represent the average pairwise nonsynonymous and synonymous nucleotide diversity, respectively, and LN and LS represent the average number of nonsynonymous and synonymous positions, respectively.

All ToxA sequences were aligned with Clustal-X and identical positions in resulting alignment were collapsed into unique haplotypes with GeneDoc to determine the polymorphic sites in the ToxA gene (Supplementary Table $\mathrm{S} 2$ presents sequences used in the ToxA haplotype network). Mutations in the ToxA coding sequence were identified manually as synonymous, nonsynonymous, or nonsense mutations. Coding sequences for all identified haplotypes were translated into amino acids with ORF-Finder (Wheeler et al. 2007) and the resulting amino acid sequences were aligned with Clustal-X. Identical positions were collapsed with GeneDoc to determine the polymorphic sites in the ToxA protein.

PCR-RFLP. Both ITS and $\beta$-tub sequences from $P$. nodorum, Pat1, Pyrenophora tritici-repentis, and B. sorokiniana were analyzed separately with NEBcutter v2.0 (Vincze et al. 2003). The HpaII/XapI restriction enzymes were chosen for PCR-RFLP analysis of ITS sequences, while the Eco31I/FokI restriction enzymes were chosen for PCR-RFLP analysis of the $\beta$-tub sequence because the position of restriction sites of these enzymes vary among the four species. Double digestion of the ITS or $\beta$-tub PCR products with the chosen restriction enzymes will give different restriction patterns that can be used to differentiate between. P. nodorum, Patl, Pyrenophora tritici-repentis, and B. sorokiniana. Restriction digestions for ITS or $\beta$-tub PCR amplicons were performed using FastDigest HpaII/XapI or Eco31I/ FokI enzymes, respectively ( $1 \mu \mathrm{l}$ each enzyme; Thermo Fisher Scientific, Canada) with $\sim 400 \mathrm{ng}$ of the PCR products $(10 \mu \mathrm{l})$ in $10 \times$ FastDigest Green buffer $(2 \mu \mathrm{l})$, with a total volume adjusted to
$30 \mu \mathrm{l}$ with nuclease-free water and incubated for $10 \mathrm{~min}$ at $37^{\circ} \mathrm{C}$. PCR-RFLP to $\beta$-xylosidase PCR amplicons, to differentiate between $P$. nodorum, Pat1, Pyrenophora tritici-repentis, and $B$. sorokiniana, was performed according to McDonald et al. (2012) using the $S c a$ I enzyme. The resulting PCR-RFLP fragments were separated by gel electrophoresis (2\% agarose) for $90 \mathrm{~min}$ at $95 \mathrm{~V}$ in $1 \times \mathrm{TBE}(\mathrm{pH}$ 8.2). The gels were stained with RedSafe and visualized on UV transilluminator. The size of digested bands was determined by comparing with a $1-\mathrm{kb}$ plus DNA ladder.

Evaluation of wheat sensitivity to SnTox1 and SnTox3. In total, 79 wheat cultivars developed and grown in Canada since 1870 were evaluated in a growth chamber for their reaction to purified SnTox 1 and SnTox3 3 days after infiltration (Table 1). Plants were grown at 18 to $20^{\circ} \mathrm{C}(16 / 8 \mathrm{~h}$ photoperiod) with a light intensity of $580 \mu \mathrm{Mol}$ and $80 \%$ relative humidity as described in Aboukhaddour et al. (2013), and were infiltrated with the effectors at the two-leaf stage. Purified heterologously expressed SnTox 1 and SnTox3 were produced and infiltrations were performed as described by Friesen and Faris (2012). Briefly, approximately $200 \mu \mathrm{l}$ of purified effector was infiltrated in the midsection of the second leaf using a needless $1 \mathrm{ml}$ syringe. The experiment was repeated at two different dates (two bio-replicates), and in each replicate four second leaves form each cultivar were infiltrated with each effector. Chinese Spring (sensitive to SnTox1, and insensitive to SnTox3) and Sumai3 (sensitive to SnTox3, and insensitive to SnTox1) were included as positive controls. The NE reaction was rated 3 to 5 days after infiltration using a 0 to 2 scale adapted from Friesen and Faris (2012) with slight modifications. Where 0 represented insensitive (no visible reaction); 1 represented sensitive (visible reaction: mainly bleaching chlorosis by SnTox 1 and/or SnTox3); and 2 represented more sensitive (stronger reaction than 1, and similar to the sensitive controls): chlorosis with SnTox1 and necrosis with collapse for SnTox3.

\section{RESULTS}

$P$. nodorum and Pat1: occurrences and tissue specialization. A total of 992 fungal isolates were recovered from grain and node samples that were collected from distanced locations in western Canada, and $238(23.9 \%)$ were designated to the genus Parastagonospora (R. Aboukhaddour, AAFC, Lethbridge, personal communication). Parastagonospora was the third most prevalent genus $(23.9 \%)$ after Alternaria (39.6\%) and Fusarium (27.8\%). Isolates belonging to these three genera represented $91.3 \%$ of collected isolates. In Scott (Saskatchewan), 50 isolates (71.4\%) recovered from nodes and 20 isolates $(28.6 \%)$ were isolated from

TABLE 2. List of PCR primers used during the current studya

\begin{tabular}{|c|c|c|c|c|}
\hline Primer & Sequence $\left(5^{\prime}-3^{\prime}\right)$ & Direction & Target gene/region & Reference \\
\hline BMB-CR & GTACACACCGCCCGTCG & Forward & ITS region & White et al. (1990) \\
\hline ITS-4B & TTCCWCCGCTTATTGATATGC & Reverse & ITS region & White et al. (1990) \\
\hline $\mathrm{T} 1$ & AACATGCGTGAGATTGTAAGT & Forward & $\beta-t u b$ & O'Donnell and Cigelnik (1997) \\
\hline $\mathrm{T} 22$ & TCTGGATGTTGTTGGGAATCC & Reverse & $\beta-t u b$ & O'Donnell and Cigelnik (1997) \\
\hline SnActinF & CTGCTTTGAGATCCACAT & Forward & Actin & Gao et al. (2015) \\
\hline SnActinR & GTCACCACTTTCAACTCC & Reverse & Actin & Gao et al. (2015) \\
\hline SnTox $1 \mathrm{cF}$ & ATGAAGCTTACTATGGTCTTGT & Forward & SnToxl & Gao et al. (2015) \\
\hline SnTox $1 \mathrm{cR}$ & TGTGGCAGCTAACTAGCACA & Reverse & SnToxl & Gao et al. (2015) \\
\hline SnTox $3 \mathrm{cF}$ & CTCGAACCACGTGGACCCGGA & Forward & SnTox3 & Gao et al. (2015) \\
\hline SnTox $3 c R$ & СTCCCCTCGTGGGATTGCCCCATATG & Reverse & SnTox3 & Gao et al. (2015) \\
\hline ToxA192 & CGTCCGGCTACCTAGCAATA & Forward & SnToxA & Friesen et al. (2006) \\
\hline ToxA1155 & TTGTGCTCCTCCTTCTCGA & Reverse & SnToxA & Friesen et al. (2006) \\
\hline TA51F & GCGTTCTATCCTCGTACTTC & Forward & SnToxA & Andrie et al. (2007) \\
\hline TA52R & GCATTCTCCAATTTTCACG & Reverse & SnToxA & Andrie et al. (2007) \\
\hline LRR.F2300 & TCCTCAAATGCATATGCCTGTGCAA & Forward & Tsn1 & Faris et al. (2010) \\
\hline LRR.R3900 & ATGCTCAAGGTTGGAAAGGGTACTG & Reverse & Tsn1 & Faris et al. (2010) \\
\hline Act-F2 & CTTAGAAGCACTTGCGGTGGAC & Forward & Actin & This study \\
\hline Act-R2 & CAAGTCCAACCGTGAGAAGATGAC & Reverse & Actin & This study \\
\hline
\end{tabular}

a The target gene/region and reference of each primer is indicated. 
grains, and were designated to the genus Parastagonospora. In Alberta, at three sites including Beaverlodge, Lacombe, and Lethbridge, $6(14 \%), 25(75.8 \%)$, and $70(76.1 \%)$ of the isolates were identified as Parastagonospora and were isolated from nodes, while $37(86 \%), 8(24.2 \%)$, and $22(23.9 \%)$ of the isolates were isolated from grains, respectively (Fig. 1). Parastagonospora isolates were initially identified using culture-based methods based on colony morphology, followed by microscopic confirmation based on the formation of subglobose pycnidia with a central ostiole, exuding hyaline aggregated conidia. A subset of 26 isolates were selected for molecular confirmation. The ITS, $\beta$-tub, and actin sequences, in addition to the effector gene sequences were confirmed. In this study, Parastagonospora isolates were grouped into two species based on ITS, $\beta$-tub, and actin sequences: P. nodorum and Patl.

Multilocus phylogenetic analysis based on ITS, $\beta$-tub, and actin sequences of 26 isolates (11 from grains and 15 from nodes) was conducted to study the genetic relationship between these isolates. A NJ phylogenetic tree showed two main clades with $100 \%$ bootstrap supporting values: i.e., a $P$. nodorum clade and a Pat 1 clade (Fig. 2). All tested $P$. nodorum isolates were mainly recovered from node samples, with only three $P$. nodorum isolates (B106-16, B313-13, and B418-11) isolated from grain samples, while all Pat1 isolates were exclusively recovered from grain samples (Fig. 2).

PCR-RFLP to differentiate between $P$. nodorum, Pat1, Pyrenophora tritici-repentis, and B. sorokiniana. Differences in the ITS and $\beta$-tub sequences of $P$. nodorum and Patl were visualized by PCR-RFLP analysis. Double digestion of ITS and $\beta$-tub PCR products with HpaII/XapI and Eco31I/FokI, respectively, clearly discriminated between the two species (Supplementary Fig. S1). Digestion of the Pat1 ITS-PCR products ( $\sim 700 \mathrm{bp})$ produced a characteristic pattern consisting of three fragments $(340+280+80 \mathrm{bp})$, while $P$. nodorum produced a different pattern consisting of four restriction fragments $(280+220+120+80 \mathrm{bp})$ (Supplementary Fig. S1A). Digestion of $\beta$-tub PCR products $(\sim 1,600 \mathrm{bp})$ also produced differentiating patterns for $P$. nodorum

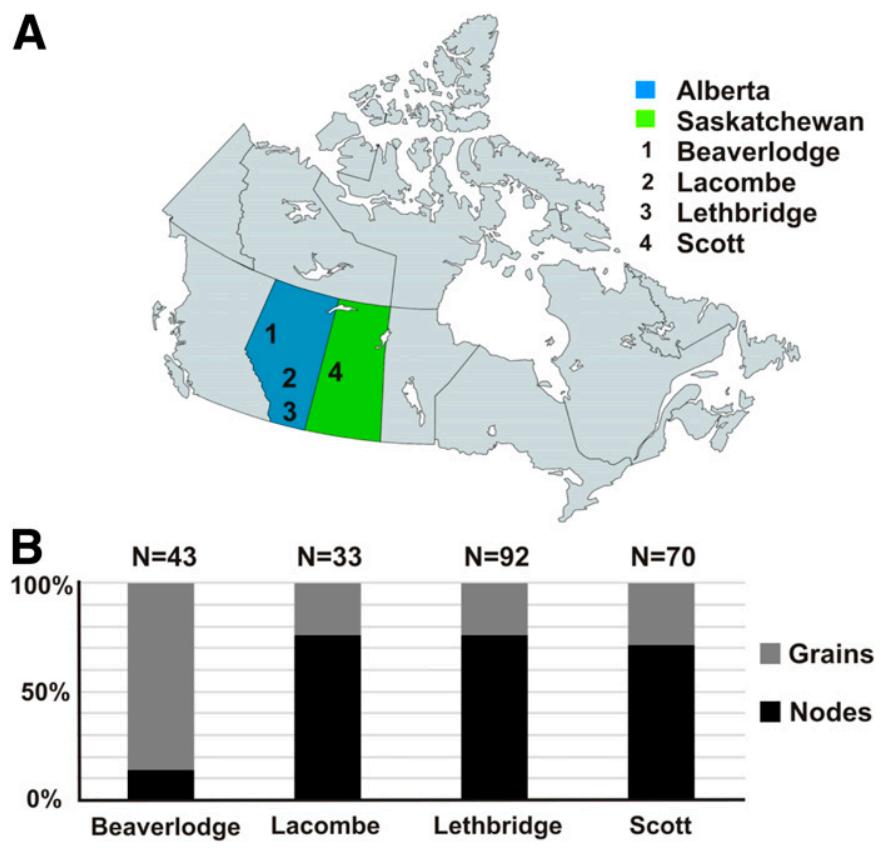

Fig. 1. A, Wheat node and grain samples were collected from three Agriculture and Agri-Food Canada (AAFC) experimental field sites in Alberta (Lethbridge, Lacombe, and Beaverlodge) and one AAFC site in Saskatchewan (Scott). B, Percentage of Parastagonospora isolates recovered from node (black) and grain (gray) samples from each location is shown, where $\mathrm{N}$ represents the total number of Parastagonospora isolates obtained from each location. and Pat 1; however, several short fragments $(<100 \mathrm{bp})$ were obtained that resulted in poor gel resolution (Supplementary Fig. S1B). Within ITS, ITS1 and ITS2 regions contain several positions that can be used to discriminate between $P$. nodorum and Pat1, and in this study ITS sequences were investigated to develop a PCR-RFLP tool that could differentiate between $P$. nodorum, Pat1, Pyrenophora tritici-repentis, and B. sorokiniana. The ITS-based PCRRFLP tool was validated in silico using ITS sequences retrieved from GenBank for P. nodorum, Pat1, Pyrenophora tritici-repentis, and $B$. sorokiniana (30 sequence each species). Accession numbers for sequences used are listed in Supplementary Table S3. All sequences tested in silico showed the expected restriction pattern for each species obtained during the in vitro PCR-RFLP experiment.

The ITS-based PCR-RFLP tool developed here was compared with a previously published $\beta$-xylosidase PCR-RFLP tool that was used to distinguish between Patl and $P$. nodorum based on polymorphisms in the $\beta$-xylosidase coding gene with the ScaI restriction enzyme. In the current study, the four fungal pathogens (P. nodorum, Pat1, Pyrenophora tritici-repentis, and B. sorokiniana) were subjected to both $\beta$-xylosidase and ITS PCR-RFLP. The results showed that $\beta$-xylosidase PCR-RFLP cleaves the Pat1 $\beta$-xylosidase PCR amplicon, while PCR amplicons from the other three species were not cleaved and gave identical patterns matching the uncut control. However, the developed ITS PCR-RFLP tool in the current study efficiently distinguished between the four species, giving the following characteristic patterns for each species: P. nodorum $(80+220+120+280$ bp $)$, Patl $(80+340+280$ bp $)$, Pyrenophora tritici-repentis $(80+80+260+140+140 \mathrm{bp})$, and B. sorokiniana $(80+100+240+140+140$ bp) (Supplementary Fig. S2).

Distribution of SnToxA, SnTox1, and SnTox3 in $P$. nodorum and Pat1. The presence or absence of SnToxA, SnTox 1, and SnTox3 was determined by PCR using specific primers (Table 2). In the 26 tested P. nodorum and Patl isolates, SnToxA, SnToxl, and SnTox3 were present in 18, 21, and 20 isolates, respectively. These three genes were detected in all tested $P$. nodorum isolates, except in isolate B106-16, which was collected from the nodes in Beaverlodge, and lacked SnTox3 (Fig. 2 and Supplementary Fig. S3). In Pat1, SnToxA was absent from the eight tested isolates, and SnTox1 and SnTox3 were present together in two isolates B306-12 and B306-13. The two Pat1 isolates B315-11 and B301-14 each encoded either SnTox1 or SnTox3, respectively (Fig. 2 and Supplementary Fig. S3). The four Pat1 isolates with detected effector genes were recovered from Beaverlodge grain samples (Fig. 2 and Supplementary Fig. S3).

SnTox1 and SnTox3 haplotypes. The SnToxl and SnTox3 gene sequences in this study were investigated. SnToxl sequences from $P$. nodorum (18) and Patl (3) were aligned with previously published SnTox 1 sequences from both species. Alignment analysis showed that three haplotypes in P. nodorum were $100 \%$ identical to SnToxl H4 (accession number JX997403), SnToxl H8 (accession number JN971688), and SnTox1 H16 (accession number JX997400). Only one SnToxl haplotype (H4) was present in the Pat1 isolates (Fig. 2). The SnTox3 gene was sequenced from 17 P. nodorum and three Pat1 isolates. A BLAST search of the SnTox3 gene from $P$. nodorum and Pat1 isolates recovered during the current study showed $100 \%$ identity to the SnTox3 haplotype H1 (Fig. 2). SnTox3 H1 was previously reported in P. nodorum SN15 (accession number FJ823644) and in Pat1 AI757 (accession number JX997415). GenBank accession numbers for SnToxl and SnTox3 generated during this study are listed in Supplementary Table S1.

Tox $A$ haplotypes in $\boldsymbol{P}$. nodorum and related species. ToxA sequences obtained in this study and in previously released data were analyzed for haplotype identification, ToxA sequences in P. nodorum, Pat1, Pyrenophora tritici-repentis, and B. sorokiniana were compared (Fig. 3A and Supplementary Table S2). In total, 26 
ToxA haplotypes worldwide were reported in all tested species, 22 in P. nodorum (H1 to $\mathrm{H} 21$, and $\mathrm{H}^{*}$ ), three in Pat1 (H1, H5, and $\left.\mathrm{H} 15\right)$; and four in Pyrenophora tritici-repentis and B. sorokiniana (H22 to H25). Sequence analysis of the ToxA gene from the Canadian $P$. nodorum isolates (18) revealed the dominance of $\mathrm{H} 5$ in all isolates harboring ToxA except for two isolates, one with haplotype H1 (B201-3) and the other (G211-5) with a novel haplotype, denoted H21 (GenBank accession MT052949). H21 is a novel haplotype we identified here for the first time, and it differs from $\mathrm{H} 5$ by a single transversion, nonsynonymous mutation at position $436(\mathrm{~T} \rightarrow \mathrm{A})$ that alters the SnToxA amino acid sequence. In H21, phenylalanine (F) is replaced by isoleucine (I) at position 147 , both of which are hydrophobic amino acids.

A total of 49 polymorphic sites were found among the 26 ToxA haplotypes (Fig. 3A). Translation of ToxA nucleotide sequences to amino acids revealed 17 synonymous, 27 nonsynonymous, and five nonsense mutations (Fig. 3B). All nonsense mutations were found only in SnToxA H3 and H17, these two haplotypes are highly divergent and differ by 2 and 3 nonsense mutations from the closest haplotypes $\mathrm{H} 20$ and H19, respectively (Fig. 4A). Two base pair substitutions $(\mathrm{G} \rightarrow \mathrm{A})$ encode for two stop codons in $\mathrm{H} 3$ (TGA $\rightarrow$ TAG), and three base pair substitutions $(\mathrm{C} \rightarrow \mathrm{T})$ encode for three stop codons in $\mathrm{H} 17$ (CAA $\rightarrow$ TAA). The presence of a premature stop codon in the ToxA reading frame indicates the nonfunctionality of these two haplotypes. A total of 26 ToxA haplotypes were described, (Figs. 3A and 4A), with some ToxA haplotypes differing by only synonymous/silent mutation(s), resulting in identical ToxA protein isoforms. In total, 18 ToxA isoforms were identified: i1 to i14 and i* in P. nodorum; i1 and i5 in Pat1; i15 and i16 in Pyrenophora tritici-repentis; and i16 and i17 in B. sorokiniana (Figs. 3B and 4A).

The strength of purifying (natural) selection on effector (ToxA) and noneffector $(\beta$-tub) genes was tested. The $\mathrm{pN} / \mathrm{pS}$ ratio was calculated to both genes in a set of 18 sequences representing 18 $P$. nodorum isolates recovered during the current study. The $\mathrm{pN} / \mathrm{pS}$ ratio was found to be higher in the ToxA gene $(0.32585)$ when

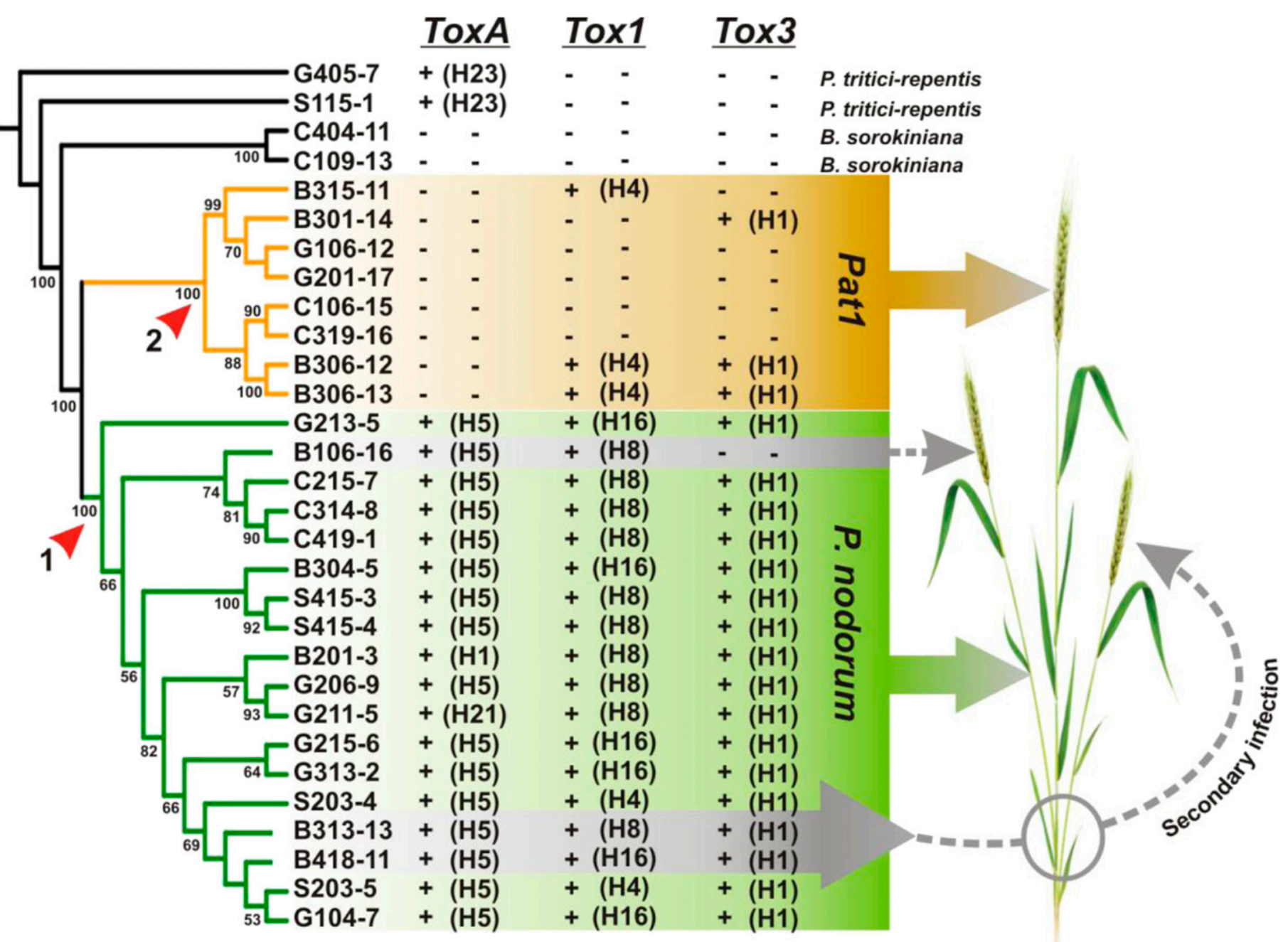

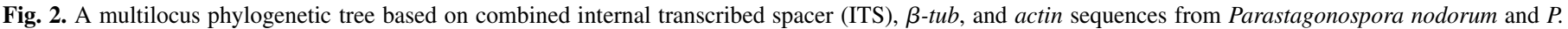

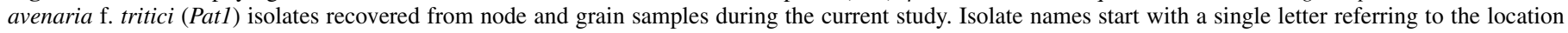

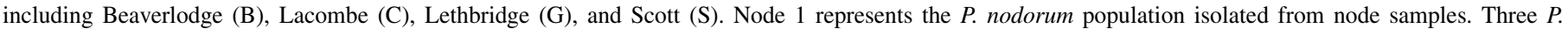

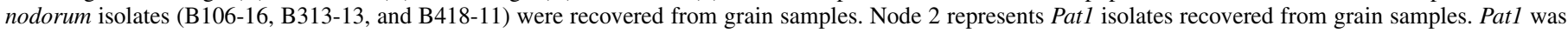

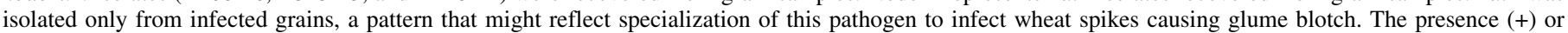

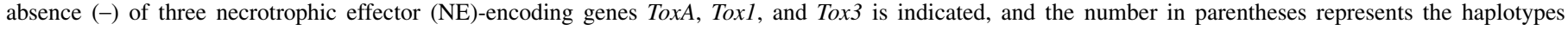

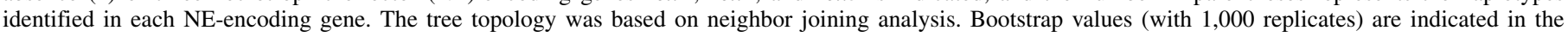

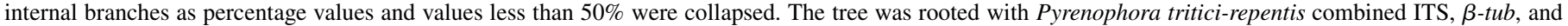
actin sequences. 
compared with the $\beta$-tub gene (0.03208). Parameters used to calculate the $\mathrm{pN} / \mathrm{pS}$ ratio and DNA polymorphism data for the two genes are listed in Supplementary Table S4.

ToxA haplotype network. A ToxA haplotype network was constructed to show the genetic relationships between the 26 haplotypes of ToxA (Fig. 4A). Ancestral ToxA haplotypes can be recognized by their internal position in the network and the wide geographic distribution (e.g., $\mathrm{H} 1$ and $\mathrm{H} 5$ ), while more recent haplotypes are found at network tips and restricted to certain regions (e.g., H2 and H4) (Fig. 4A). Haplotype H1 appears to be the ancestral haplotype resting at the center of the network, and is the most widespread haplotype reported in North America, Europe, Africa, Australia, central Asia. Middle East and China (Fig. 4B). From the network, a prevalence of nonsynonymous over synonymous mutations was observed (Fig. 4A). It appears that possible intermediate haplotypes (represented by small black circles) are missing from the network (Fig. 4A). The majority of ToxA haplotypes in the network were reported from P. nodorum, 22 haplotypes were identified in P. nodorum ( $\mathrm{H} 1$ to $\mathrm{H} 21$, and $\mathrm{H}^{*}$ ) and three were identified in Pat1 (H1, H5, and H15). Haplotypes H1 and $\mathrm{H} 14$ are identical at the exon sequence and encoded for the same ToxA protein isoform (i2); $\mathrm{H} 14$ differs from $\mathrm{H} 1$ by one nucleotide in the intron sequence. Combinations of four haplotypes were identified in Pyrenophora tritici-repentis and B. sorokiniana, but not yet in P. nodorum or Pat1 (denoted H22 to H25). Haplotypes
$\mathrm{H} 22$, H23, and $\mathrm{H} 24$ were present in Pyrenophora tritici-repentis, while $\mathrm{H} 23$ and $\mathrm{H} 25$ were found in B. sorokiniana (Fig. 4A and B). Three mutations (positions 102, 297, and 487) in the loop between haplotypes $\mathrm{H} 1, \mathrm{H} 5, \mathrm{H} 8$, and $\mathrm{H} 13$ are shown twice in the network because of homoplasy in the network due to intralocus recombination events (Figs. 3A and 4A).

Sensitivity to SnTox1 and SnTox3, and prevalence of the Tsn 1 gene. In total, 79 Canadian wheat cultivars representing wheat development since 1870 were tested for sensitivity to SnTox 1 and SnTox $3 ; 26(32.9 \%)$ and $45(56.9 \%)$ cultivars were sensitive to SnTox1 and SnTox3, respectively (Fig. 5). Sixteen cultivars (20.2\%) were sensitive to both SnTox1 and SnTox3, and the sensitivity ranged from sensitive (rated as 1) to more sensitive (rated as 2) (Table 1 and Fig. 5). The presence of Tsn1, the ToxA-sensitivity gene in wheat, was screened by PCR in 61 cultivars using LRRbinding primers and the results showed that 36 cultivars (59\%) were found to harbor the Tsn1 gene (Fig. 5).

\section{DISCUSSION}

In this study, isolates belonging to Parastagonospora spp., $P$. nodorum, and Patl together, were the third most frequently recovered genus (after Alternaria and Fusarium) from wheat nodes and grains collected from distanced locations in western Canada. P. nodorum, Pat1, and other related species are often found together
A

\begin{tabular}{|l|l|l|}
\hline \multicolumn{2}{|c|}{$114 \mathrm{nts}$} & $354 \mathrm{nts}$ \\
\hline Pre-D. & Pro-Domain & Mature-Domain \\
\hline
\end{tabular}

Site\# \#

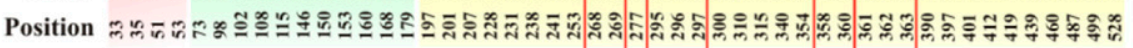

Consensus C C C C GAT C G G C C C C G C C C C C G C GGGGGAA GACA CACAACT C G C G T C A TA

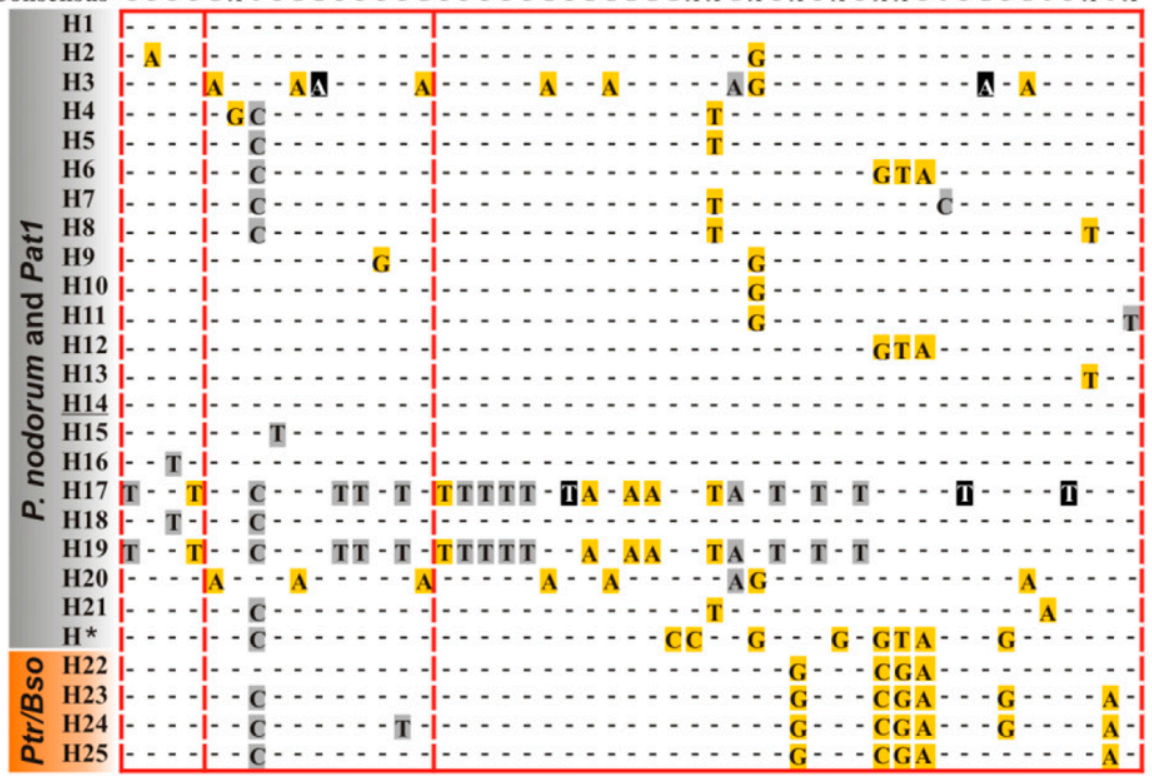

Synonymous mutation

Non-synonymous mutation

Nonsense mutation
B

\begin{tabular}{|l|l|}
\hline 22 aa & 38 aa \\
\hline
\end{tabular}

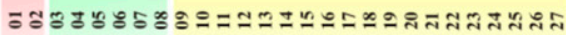

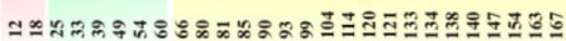
APGEEWRRSGQDGGEININQWLRFQIS

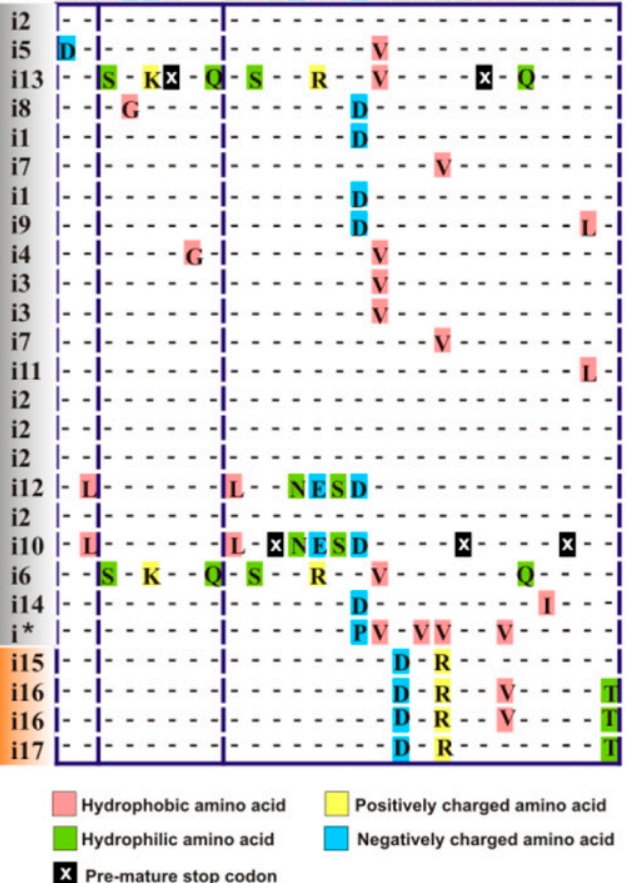

Fig. 3. A, ToxA gene haplotype sequence alignment in Parastagonospora nodorum and related leaf spot pathogens. ToxA gene consisting of 537 nucleotides (excluding intron) encoding for 178 amino acids, divided into three regions: Predomain (signal sequence), prodomain (N-domain), and the mature-domain. Nucleotide positions are numbered relative to ToxA gene start codon and the consensus ToxA sequence is shown in black boxes. A total of 49 polymorphic sites were found among $26\left(\mathrm{H} 1-\mathrm{H} 25\right.$, and $\left.\mathrm{H}^{*}\right)$ different ToxA haplotypes (including the in silico identified haplotype $\left.\mathrm{H}^{*}\right)$. Mutations within the same codon are marked with a gray/red box. Synonymous, nonsynonymous, and nonsense mutations are shown with gray, yellow, and black backgrounds, respectively. H14 (underlined) differs from $\mathrm{H} 1$ by a single mutation in the intron. B, Amino acid sequence alignment of 18 ToxA isoforms (i1-i17 and i*). Some ToxA isoforms are found to be identical and have been given the same isoform number. A total of 27 polymorphic sites were observed, the consensus amino acid sequence is indicated in the top line using the single letter amino acid code, and the background color indicates the amino acid properties. Supplementary Tables S1 and S2 provide information about sequences used to generate this figure. 
and are very similar at the morphological and molecular levels, and such similarity may lead to inaccurate interpretation about the prevalence of these pathogens. In Canada, and many parts of the world, leaf spot diseases are caused by several species (disease complex), but all exhibit very similar symptoms of necrotic lesions on the infected leaves, with most causal agents belonging to species within Parastagonospora, Pyrenophora, and related genera. These pathogens, and even several races of the same pathogen, can be

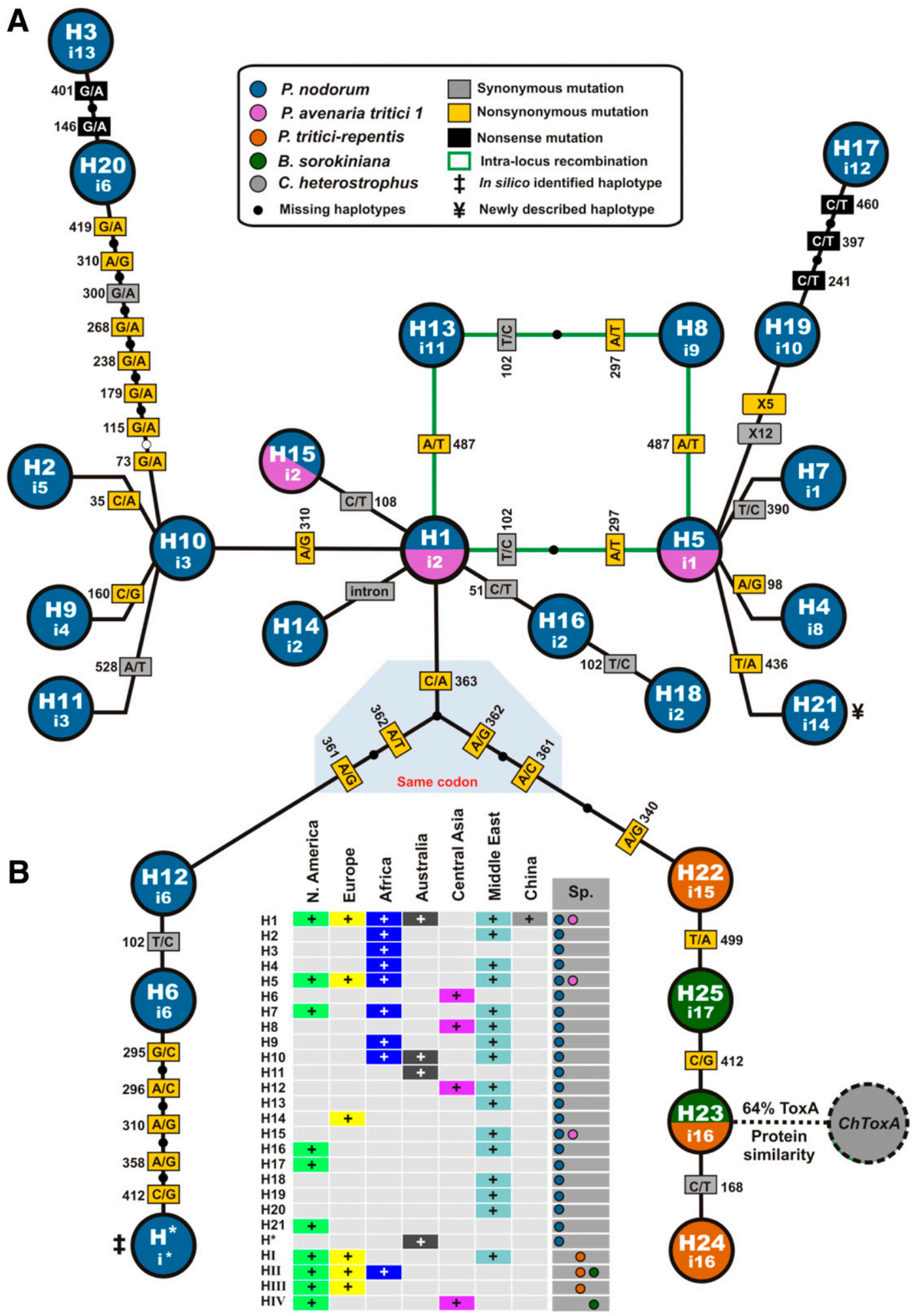

Fig. 4. A, ToxA haplotype network in Parastagonospora nodorum and other related species. A total of 26 ToxA haplotypes were described, 25 haplotypes were previously published $\left(\mathrm{H} 1-\mathrm{H} 20, \mathrm{H} 22-\mathrm{H} 25\right.$, and $\left.\mathrm{H}^{*}\right)$, and a novel haplotype was characterized during the current study (H21). $\mathrm{H} 21$ is a novel haplotype from a $P$. nodorum isolate recovered from a wheat node sample collected from Lethbridge, AB, Canada. Gray, yellow, and black boxes represent synonymous, nonsynonymous, and nonsense mutations, respectively, and numbers beside each box represent the nucleotide position relative to the ToxA start codon. Three mutations (positions 102, 297, and 487) in the loop between haplotypes H1, H5, H8, and H13 (green line) are shown twice due to intralocus recombination events. B, Geographic distribution of ToxA haplotypes in different geographic regions and the species that were found to contain each haplotype. A ToxA-like gene was identified in Cochliobolus heterostrophus (ChToxA) with 64\% protein identity to Pyrenophora tritici-repentis ToxA H23. This Figure was adapted from Stukenbrock and McDonald (2007), McDonald et al. (2013), McDonald et al. (2018), and Ghaderi et al. (2020). 
isolated from the same field, the same plant, and even the same lesion, but it is very difficult or even impossible to accurately define the causal agent for a leaf spot disease based on the symptoms alone. Parastagonospora-like species infecting cereals were initially identified based on spore morphology, sexual reproduction, and host specialization (Shaw 1957a, b). Later, Parastagonospora species associated with cereals were studied at the molecular level to define the genetic relationships among these species. P. nodorum can infect both wheat and barley with two biotypes identified based on host specificity on $\mathrm{PN}-\mathrm{w}$ and $\mathrm{PN}-\mathrm{b}$, respectively (Martin and Cooke 1979).

A PCR-RFLP tool was developed to distinguish between the four species associated with the leaf spot complex in North America, P. nodorum, Pat1, Pyrenophora tritici-repentis, and B. sorokiniana (Supplementary Fig. S2). A previously developed PCR-RFLP tool was used to distinguish between P. nodorum and Patl by digesting the $\beta$-xylosidase gene PCR amplicon with ScaI (McDonald et al. 2012). This digestion resulted in unique RFLP patterns for each pathogen (McDonald et al. 2012). However, the use of $\beta$-xylosidase as a marker was not tested with other closely related pathogens like Pyrenophora tritici-repentis and $B$. sorokiniana. In addition, only a few $\beta$-xylosidase sequences were available in GenBank to validate that this molecular marker could differentiate between isolates of different origins. In the current study, we developed a new PCRRFLP protocol based on sequence polymorphisms in the ITS region
A

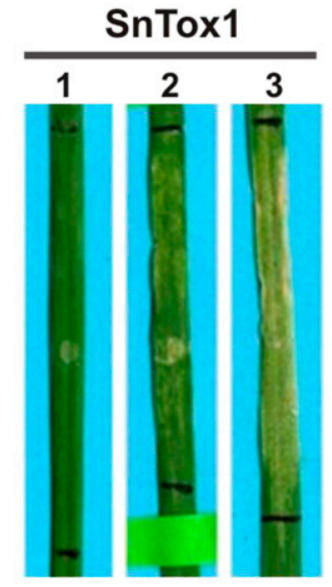

SnTox3

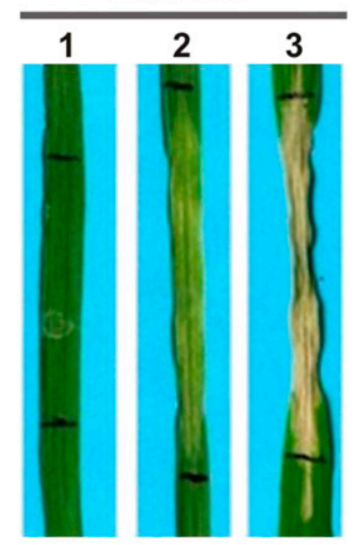

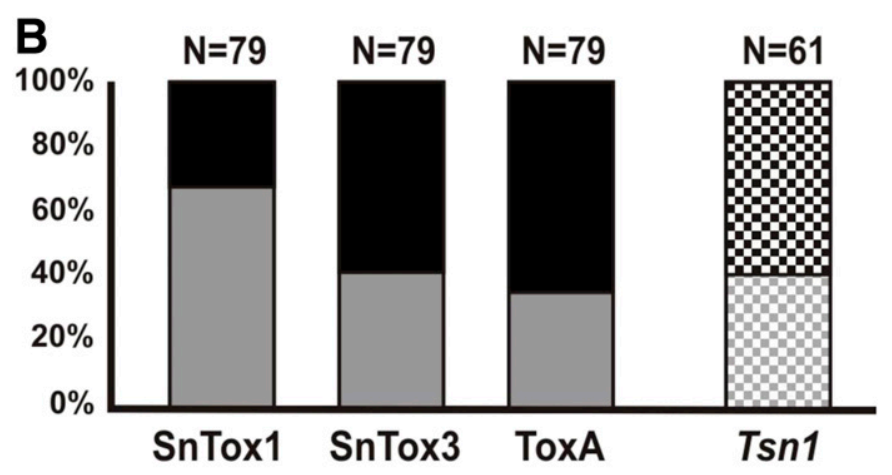

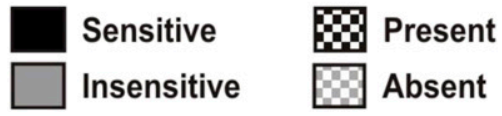

Fig. 5. A, Reaction of wheat cultivars to SnTox 1 and SnTox3. Reaction type 0 represents an insensitive reaction, while type 1 and 2 represent sensitive reactions, with 2 more pronounced than 1 reaction. Plants were infiltrated with the purified necrotrophic effectors (NEs) and scanned 4 days after. B, The percentage of sensitive and insensitive genotypes to each NE and the total number of tested wheat genotypes $(n=79)$ are indicated. In addition, PCR screening of $T s n 1$ was done in a subset of Canadian wheat genotypes $(n=61)$. that could differentiate between $P$. nodorum, Pat1, Pyrenophora tritici-repentis, and B. sorokiniana (Supplementary Fig. S2). The tools we developed were validated in silico with additional P. nodorum, Pat1, Pyrenophora tritici-repentis and B. sorokiniana sequences ( 30 sequences from each species). These sequences were retrieved from GenBank, and acquired from isolates of different geographic origins (Supplementary Table S1).

In the current study, $P$. nodorum was recovered from both node and grain samples, while Patl was recovered only from grains. Similarly, $111 P$. avenaria f. tritici isolates from a global collection of 355 Parastagonospora isolates including 48 P. avenaria $\mathrm{f}$. tritici isolates from the Canadian prairies, were all isolated from grains, while 244 P. nodorum isolates were recovered from both nodes and grains (McDonald et al. 2012). Based on the distribution pattern of both $P$. nodorum and Pat1 in node and grain samples, it was suggested that wheat leaf blotch is caused primarily by $P$. nodorum, while wheat glume blotch was likely caused by both $P$. nodorum and Patl (McDonald et al. 2012). The higher relative abundance of $P$. nodorum in stem/node samples may reflect a higher specificity of this pathogen to colonize wheat stems/node and leaves compared with grains. Indeed, all $P$. nodorum isolates tested harbored SnToxA, SnToxl, and SnTox3 genes, with the exception of one isolate that lacked the SnTox3 gene. Necrotrophic effectors facilitate necrotic/ chlorotic development on the leaves, $P$. nodorum can colonize the nodes (hence 'nodorum') as an overwintering strategy. $P$. nodorum overwinters on wheat residue in the form of pseudothecia and/or pycnidia (Duczek et al. 1999). These overwintering structures can survive up to 3 years or longer, providing a source of inoculum for the next growing season (Arseniuk et al. 1998). It is worth noting, that the Pat1 isolates tested here generally lacked the NE genes unlike the $P$. nodorum isolates (Fig. 2). Although this finding is based on a small number of Patl isolates, recovering Pat 1 only from grain samples may explain the host tissue specialization of Patl on grains versus leaves and nodes, and vice versa for $P$. nodorum. Moreover, these necrotrophic effectors may have additional roles in the evolution of pathogen specialization on various host tissues.

$P$. nodorum overwinters by forming its fruiting bodies on crop residue, and upon the start of the growing season and when the fruiting bodies are matured, the sexual ascospores are released and disperse by wind over long distances to initiate the infection (Bathgate and Loughman 2001). During the growing season, the fungus produces its asexual spores that can travel short distances by rain-splash (Eyal et al. 1987). The asexual spores are typically produced and released from the infected tissues multiple times during the growing season and will provide secondary inoculum to spread the infection up in the crop canopy (Fig. 2). The SnToxA produced by $P$. nodorum infecting isolates will be internalized into the cells of wheat genotypes carrying the Tsnl gene, then it will interact with the wheat chloroplast localized protein, the ToxA binding protein 1 (Manning et al. 2007). SnToxA is a virulence factor in $P$. nodorum and this explains the capability of $P$. nodorum to infect and colonize green tissues (leaf and stem) in susceptible wheat lines.

ToxA was suggested to have been transferred from $P$. nodorum to Patl by hybridization during a speciation event (McDonald et al. 2013), and as wheat stem and grain differ in cell structure and tissue type, ToxA in Patl may have been subjected to gene loss due to the specialization of Pat1 in infecting grain tissue. Other virulence factor(s) may have evolved in Pat1 to enable it to infect the glume/ grain tissues, while losing ToxA, affecting the capacity of Patl to infect leaves. All Patl isolates identified during the current study were recovered from grain samples and none of these isolates had the ToxA gene. In other pathogens such as Fusarium spp., the ability to infect certain host tissue was correlated to the pathogens ability to produce trichothecene. The wheat spikes and stems were more likely to be infected by trichothecene-producing strains than were roots (Jansen et al. 2005; Winter et al. 2019). Additionally, exposing plant leaf tissue to high deoxynivalenol (DON) concentrations 
resulted in plasmalemma damage, followed by photosynthetic pigment loss from the chlorophyll (Bushnell et al. 2010). The role of trichothecenes in inhibition of protein biosynthesis (Miller and Ewen 1997) and lipid peroxidation (Rizzo et al. 1994), combined with the damage to photosynthetic pigments, might explain the organ/tissue-specific aggressiveness and explain why the green pigmented plant tissues (spike and stem base) were more affected by trichothecenes than nonpigmented tissues (root).

$P$. nodorum and Pat1 genetic variability and haplotypes distribution. SnToxA, SnTox1, and SnTox3 were detected in all tested $P$. nodorum isolates, except in one isolate in which the SnTox3 gene was absent (Fig. 2). None of the tested Patl isolates encoded SnToxA, and only four isolates had SnToxl and/or SnTox3. However, ToxA was previously detected in Patl isolates from North America and Iran (Ghaderi et al. 2020; McDonald et al. 2013). The frequencies of SnTox1 and SnTox3 in P. nodorum/Pat1 isolates in the current study were consistent with what was previously found in a North America and worldwide collection (McDonald et al. 2013). Before this study, SnTox3 was rarely found in Pat1, having been detected in only a single isolate out of $152(0.7 \%)$, despite the fact that 108 Patl isolates were of Canadian origin (McDonald et al. 2013). Interestingly, our results showed SnTox3 to be present in three out of eight tested Patl isolates recovered from Beaverlodge in northern Alberta, indicating variable geographical distribution of this gene either due to the selection pressure from a specific environment or from locally planted host genotypes (Fig. 2).

The SnToxA and SnToxl genes exhibit higher sequence diversity in comparison with SnTox3 (Liu et al. 2012; McDonald et al. 2013). SnToxl and SnTox3 were only detected in P. nodorum and Pat1, and unlike SnToxA, were never reported in other species. A total of 22 SnToxl haplotypes were found in P. nodorum and only one SnToxl haplotype (identical to $P$. nodorum H4) was reported in Pat1 (McDonald et al. 2013; Ghaderi et al. 2020). Conversely, a total of 13 SnTox3 haplotypes were also reported in $P$. nodorum and only one SnTox3 (identical to P. nodorum H1) was reported in Pat1 (McDonald et al. 2013; Ghaderi et al. 2020).

Each effector-coding gene has several haplotypes that may code for a different toxin isoform. These isoforms may contribute to different levels of symptom development, and may have specific geographical distributions or preferable presence in certain species (Tan et al. 2012). Different wheat lines carrying identical Tsn1 alleles varied in their sensitivity to SnToxA, and this was mainly due to the varying levels of ToxA isoform activities (Tan et al. 2012). A direct correlation was found between the fitness of the pathogen and the secreted toxin isoform. For example, the ToxA isoform encoded by the haplotype $\mathrm{H} 4$, induced higher necrosis activity than the isoform encoded by $\mathrm{H} 9$, even when infiltrated into the same sensitive wheat genotype. ToxA encoded by $\mathrm{H} 4$ also induced higher sporulation than that encoded by H9 (Tan et al. 2012).

ToxA haplotype network. An updated ToxA haplotype network is presented to include all previously identified ToxA haplotypes from all cereal leaf spot pathogens and the novel SnToxA haplotype (H21), which is reported for the first time in this study (Fig. 4A). This network presents a comprehensive view to illustrate the evolutionary patterns of the different ToxA haplotypes to date in the four cereal leaf spot pathogenic species ( $P$. nodorum, Pat1, Pyrenophora tritici-repentis, and B. sorokiniana). In total, we report on 26 ToxA haplotypes detected around the world in all tested species, including the novel $\mathrm{H} 21$ present in $P$. nodorum from the current study. Twenty-two haplotypes ( $\mathrm{H} 1$ to $\mathrm{H} 21$, and $\mathrm{H}^{*}$ ) are found in P. nodorum (Friesen et al. 2006; Ghaderi et al. 2020; Kamel et al. 2019; McDonald et al. 2013; Stukenbrock and McDonald 2007; and this study). Haplotype $\mathrm{H}^{*}$ was identified in silico in a P. nodorum isolate originating from Australia (GenBank accession MH511823), and because the authors did not obtain the isolate Fr15-02 and confirm the sequence of ToxA, they did not designate a specific haplotype number and rather denoted this as haplotype $\mathrm{H}^{*}$ (Kamel et al. 2019). In Pat1, three haplotypes, H1, H5, and H15, have been identified so far (Ghaderi et al. 2020; McDonald et al. 2013); however, ToxA was not detected in the Patl isolates in this study, likely due to the limited number of isolates tested.

In Pyrenophora tritici-repentis, only three ToxA haplotypes previously denoted (H14, H15, and H16) were identified and are being recoded here as $\mathrm{H} 22, \mathrm{H} 23$, and $\mathrm{H} 24$, respectively, to avoid misidentification with the SnToxA haplotypes H14, H15, and H16. In Pyrenophora tritici-repentis, H24 (previously H16) was reported from a Canadian isolate, 86-124 (Ballance et al. 1996; accession U79662), and H23 (previously H15) was present in isolate Pt-1c collected in the United States (Ciuffetti et al. 1997; accession AF004369). Later, H22 (previously H14) was found in 54 Pyrenophora tritici-repentis isolates originating from Europe, North America, and South America (Friesen et al. 2006), and recently $\mathrm{H} 23$ (previously $\mathrm{H} 15$ ) was the only reported haplotype in Pyrenophora tritici-repentis isolates from the province of Alberta, Canada and Tunisia (Kamel et al. 2019). Recently, a homolog of ToxA was reported in 35 B. sorokiniana isolates from Australia (McDonald et al. 2018). Sequence analysis of Australian B. sorokiniana ToxA revealed two haplotypes, one was identical to Pyrenophora tritici-repentis ToxA $\mathrm{H} 23$, and the other differed by a single nonsynonymous mutation (position 412; $\mathrm{C} \rightarrow \mathrm{G}$ ) (denoted here $\mathrm{H} 25$ ), and was unique to B. sorokiniana. In the United States, ToxA was detected in 13 B. sorokiniana isolates out of 15 tested (Friesen et al. 2018). In India, a larger number of B. sorokiniana isolates (110) were collected from different regions, and ToxA H23 and/or $\mathrm{H} 25$ were detected in 77 isolates (70\%) (Navathe et al. 2020). Two B. sorokiniana ToxA haplotypes were present in the Indian $B$. sorokiniana, isolate and were similar to the two haplotypes present in B. sorokiniana from Australia and the United States (Friesen et al. 2018; McDonald et al. 2018). In the current study, we screened only two B. sorokiniana isolates that were recovered from grains in Alberta (Lacombe), and no ToxA was detected, likely due to the limited number of isolates tested.

In this North America study, we reported the presence of six ToxA haplotypes ( $\mathrm{H} 1, \mathrm{H} 5, \mathrm{H} 7, \mathrm{H} 16, \mathrm{H} 17$, and $\mathrm{H} 21)$ in $P$. nodorum including the recent addition of $\mathrm{H} 21$, with $\mathrm{H} 1$ and $\mathrm{H} 5$ as the most dominant (Ghaderi et al. 2020; McDonald et al. 2013; Stukenbrock and McDonald 2007). Among all ToxA haplotypes, H1 had the widest geographical distribution, and was detected in isolates from North America, Europe, Africa, Australia, central Asia, Middle East, and China (Fig. 4B). The haplotypes H1, H5, and H21 are closely related in the evolutionary network, $\mathrm{H} 5$ differs from $\mathrm{H} 1$ in two nucleotides and from $\mathrm{H} 21$ in one nucleotide (Fig. 4A). H21 was recovered from a node sample collected from southern Alberta (Lethbridge). $\mathrm{H} 21$ and $\mathrm{H} 5$ differed in a single transversion mutation $(\mathrm{T} \rightarrow \mathrm{A})$ at position 439 . This changes phenylalanine $(\mathrm{F})$ to isoleucine (I) in $\mathrm{H} 21$, both being hydrophobic amino acids. This mutation occurs in the beta-sheet $\beta-6$ and very close to the Arg-Gly-Asp (RGD) loop which is directly involved in recognition events required for ToxA action (Sarma et al. 2005). This mutation could affect the ToxA protein encoded by $\mathrm{H} 21$, and may affect pathogen fitness. An experimental confirmation is needed to test this hypothesis.

The dominance of $\mathrm{H} 5$ in Canadian $P$. nodorum isolates may be due to the selection pressure imposed by a certain host genotype on the pathogen to select for certain effector haplotypes to be fixed in the pathogen population as it may contribute to increased pathogen fitness and virulence (McDonald et al. 2013). The prevalence of the ToxA gene (over 90\%) in Pyrenophora tritici-repentis and $P$. nodorum isolates in North America can be explained by the prevalence of Tsn1-carrying wheat cultivars in North America (Aboukhaddour et al. 2013; Richards et al. 2019). Some of the reported ToxA haplotypes are uniquely present in a certain region, for example $\mathrm{H} 3$ was only found in Africa and $\mathrm{H} 6$ only detected in Central Asia; similarly unique to Australia was H11 and H*. H17 was only found in North America, and H14 only in Europe. Africa and the Middle East share haplotypes that are not reported elsewhere such as $\mathrm{H} 2, \mathrm{H} 4$, and H9. However, at the species level, 
19 haplotypes were unique to $P$. nodorum, and only three haplotypes were present in both $P$. nodorum and Pat1. In contrast, Pyrenophora tritici-repentis and B. sorokiniana shared the same $\mathrm{H} 23$.

Sensitivity to ToxA, SnTox1, and SnTox3. In the present study, the sensitivity to $P$. nodorum effectors was reported for the first time for wheat cultivars in Canada. From the 79 selected cultivars developed over the last century, sensitivity to SnTox3 was prevalent in $56.9 \%$ of them. Conversely, sensitivity to SnTox1, which has weaker activity than SnTox3, was present, but in a lower percentage $(32.9 \%)$ of tested cultivars. The sensitivity to ToxA as concluded from the presence of $T s n 1$ was dominant, being detected in $59 \%$ of the tested cultivars. This is relatively consistent with previous results where sensitivity in Canadian cultivars to Pyrenophora tritici-repentis ToxA was estimated at $64.1 \%$ (Lamari et al. 2005; Tran et al. 2017). In Lamari et al. (2005) and Tran et al. (2017), sensitivity to ToxA was evaluated using the purified ToxA effector from the Pyrenophora tritici-repentis isolate 86-124, and in this isolate the single copy ToxA gene is identified as haplotype $\mathrm{H} 24$ (previously H16). H24 differs from SnToxA (H1), used currently to infiltrate wheat leaves, in only four amino acids. Both haplotypes, $\mathrm{H} 24$ and H1, target the same protein encoded by the Tsn1 gene in sensitive wheat lines. The ToxA from these two pathogens has only one amino acid substitution in the solvent exposed loop at position $138, \mathrm{~L} \rightarrow \mathrm{V}$, and has an identical RGD motif, and was predicted to behave similarly when interacting with the ToxA receptor in the wheat host.

The majority $(90 \%)$ of screened wheat cultivars in this study were sensitive to at least one NE, and $34.6 \%$ were sensitive to both SnToxA and SnTox3. Only 10\% were insensitive to all three NEs. 'Thatcher' and '5701PR' were previously rated heterogeneous in reaction to Pyrenophora tritici-repentis ToxA (Tran et al. 2017). However, Lamari et al. (2005) reported that these two cultivars were rated insensitive, and this was the most likely reaction, as Tsnl was absent in these lines in the current study. 'Thatcher' replaced the stem rust susceptible cultivar Marquis in 1935 and predominated on the Canadian Prairies until 1968 (Aboukhaddour et al. 2020; McCallum and DePauw 2008). In the 1970s, the rise of Pyrenophora tritici-repentis as a destructive wheat pathogen in North America and worldwide was explained by the adoption of zero-till practice (reviewed in De Wolf et al. 1998). However, zerotillage was not a common practice in North America until the 1990s (Awada et al. 2014; Friedrich et al. 2012), and the emergence of Pyrenophora tritici-repentis as a serious pathogen on wheat can be alternatively explained by the horizontal gene transfer of ToxA gene into Pyrenophora tritici-repentis (Friesen et al. 2006), coinciding with the wide adoption of ToxA-sensitive wheat in North America and Australia and other parts of the world (Lamari et al. 2005; Tran et al. 2017). In the late 1930s, tan spot outbreaks reaching epidemic levels were reported in the Canadian Prairies (Conners 1941; Conners and Savile 1944; Creelman 1964). There was a gap of a few decades between the initial epidemics in the late 30 s and the serious ones of the 70s, and this can be explained by the prevalence of ToxAinsensitive 'Thatcher' between these epidemics, while sensitive lines predominated before and after (Lamari et al. 2005).

The wide cultivation of sensitive wheat in Canada will exert selection pressure on the pathogen to select and evolve virulence. For example, the predominance of ToxA-producing Pyrenophora tritici-repentis races in North America was explained by the prevalence of Tsn1-carrying cultivars (Aboukhaddour et al. 2013; Lamari et al. 2005). The prevalence of ToxA in $P$. nodorum varied greatly and was present across different geographical regions. For instance, SnToxA was present in only $6 \%$ of $P$. nodorum isolates from China, whereas its frequency in Australian was 97\%, with a global average of $\sim 40 \%$ (McDonald et al. 2013). Maintaining effector sensitivity genes in wheat cultivars will select for effector producing pathogens and will lead to the emergence of new, and more-virulent effector haplotypes.
The strength of purifying selection of ToxA and $\beta$-tub genes in a subset of $18 P$. nodorum isolates were compared in this study. The $\mathrm{pN} / \mathrm{pS}$ ratio was found to be significantly higher in ToxA when compared with $\beta$-tub. A similar pattern was reported in another wheat pathogen, Zymoseptoria tritici, where genes predicted to encode effector proteins showed significantly higher $\mathrm{pN} / \mathrm{pS}$ ratios compared with other genes (Grandaubert et al. 2019). The authors speculate that this pattern was due to rapid evolution through positive selection of this particular category of genes, and the higher $\mathrm{pN} / \mathrm{pS}$ ratio in these genes may reflect less efficient purifying selection at sites linked to positively selected mutations.

In this study, we demonstrated the importance of exploring and evaluating the different effector haplotypes present in the Canadian leaf spot pathogens. The screening of cultivars with these effectors is an important resource to be considered in developing new resistant cultivars. Moreover, the molecular tools developed in the current study to differentiate between different pathogenic species, if utilized in regular surveys, should enhance our understanding of the leaf spot complex in Canada and worldwide, while also facilitating our ability to improve management practices.

\section{ACKNOWLEDGMENTS}

We thank Gaganpreet Dhariwal, Kaveh Ghanbarnia, Kieran McCormack, Nicola Schatz (AAFC-Lethbridge), Noryne Rauhala, and Jackie Busaan (AAFC-Lacombe) for assistance in various aspects of this work from providing samples to culturing pathogens, infiltrating effectors, and DNA extraction; Bruce McDonald, Institute of Integrative Biology, ETH Zürich, Zürich, Switzerland, for providing us with unpublished SnToxA sequences to update the haplotype network; and Pierre Gladieux, Megan McDonald, and the anonymous reviewer for comments and suggestions that helped improve this manuscript.

\section{LITERATURE CITED}

Aboukhaddour, R., Fetch, T., McCallum, B. D., Harding, M. W., Beres, B. L., and Graf, R. J. 2020. Wheat diseases on the prairies: A Canadian story. Plant Pathol. 69:418-432.

Aboukhaddour, R., Turkington, T. K., and Strelkov, S. E. 2013. Race structure of Pyrenophora tritici-repentis (tan spot of wheat) in Alberta, Canada. Can. J. Plant Pathol. 35:256-268.

Altschul, S. F., Gish, W., Miller, W., Myers, E. W., and Lipman, D. J. 1990. Basic local alignment search tool. J. Mol. Biol. 215:403-410.

Andrie, R. M., Pandelova, I., and Ciuffetti, L. M. 2007. A combination of phenotypic and genotypic characterization strengthens Pyrenophora triticirepentis race identification. Phytopathology 97:694-701.

Arseniuk, E., Góral, T., and Scharen, A. 1998. Seasonal patterns of spore dispersal of Phaeosphaeria spp. and Stagonospora spp. Plant Dis. 82:187-194.

Awada, L., Lindwall, C. W., and Sonntag, B. 2014. The development and adoption of conservation tillage systems on the Canadian Prairies. Int. Soil Water Conserv. Res. 2:47-65.

Ballance, G. M., Lamari, L., Kowatsch, R., and Bernier, C. C. 1996. Cloning, expression and occurrence of the gene encoding the Ptr necrosis toxin from Pyrenophora tritici-repentis. Mol. Plant Pathol. Online 1209. http:// www.bspp.org.uk/mppol/1996/1209ballance/

Bathgate, J. A., and Loughman, R. 2001. Ascospores are a source of inoculum of Phaeosphaeria nodorum, P. avenaria f. sp. avenaria and Mycosphaerella graminicola in Western Australia. Australas. Plant Pathol. 30:317-322.

Bennett, R. S., Milgroom, M. G., Sainudiin, R., Cunfer, B. M., and Bergstrom, G. C. 2007. Relative contribution of seed-transmitted inoculum to foliar populations of Phaeosphaeria nodorum. Phytopathology 97:584-591.

Boots, E., Liew, A., Wiens, J., and Kutcher, H. 2019. Leaf spot diseases of wheat in Saskatchewan in 2018. Can. J. Plant Pathol. 41:104-105.

Bushnell, W. R., Perkins-Veazie, P., Russo, V. M., Collins, J., and Seeland, T. M. 2010. Effects of deoxynivalenol on content of chloroplast pigments in barley leaf tissues. Phytopathology 100:33-41.

Chang, K., Nyandoro, R., Xi, K., Kumar, K., Strelkov, S., and Capettini, F. 2019. The occurrence of cereal crop diseases in northeast Alberta in 2018. Can. J. Plant Pathol. 41:109-111.

Ciuffetti, L. M., Tuori, R. P., and Gaventa, J. M. 1997. A single gene encodes a selective toxin causal to the development of tan spot of wheat. Plant Cell 9: 135-144. 
Conners, I. L. 1941. Diseases in cereal crops. Twenty-First Annual Report of the Canadian Plant Disease Survey: Dominion of Canada Department of Agriculture Science Service, 6. I. L. Conners, ed. The Canadian Phytopathological Society.

Conners, I. L., and Savile, D. B. O. 1944. Diseases in cereal crops. TwentyFourth Annual Report of the Canadian Plant Disease Survey: Dominion of Canada Department of Agriculture Science Service, 5. I. L. Conners and D. B. O. Savile, eds. The Canadian Phytopathological Society.

Creelman, D. 1964. Diseases of cereal crops. Pages 15-21 in: Forty-Fourth Annual Report of the Canadian Plant Disease Survey: Dominion of Canada Department of Agriculture Science Service. I. L. Conners and D. B. O. Savile, eds. The Canadian Phytopathological Society.

De Wolf, E. D., Effertz, R. J., Ali, S., and Francl, L. J. 1998. Vistas of tan spot research. Can. J. Plant Pathol. 20:349-370.

Duba, A., Goriewa-Duba, K., and Wachowska, U. 2018. A review of the interactions between wheat and wheat pathogens: Zymoseptoria tritici, Fusarium spp. and Parastagonospora nodorum. Int. J. Mol. Sci. 19:1138.

Duczek, L., Sutherland, K., Reed, S., Bailey, K., and Lafond, G. 1999. Survival of leaf spot pathogens on crop residues of wheat and barley in Saskatchewan. Can. J. Plant Pathol. 21:165-173.

Eyal, Z., Scharen, A. L., Prescott, J. M., and van Ginkel, M. 1987. The Septoria Diseases of Wheat: Concepts and Methods of Disease Management. CIMMYT, Texcoco, Mexico.

Faris, J. D., Liu, Z., and Xu, S. S. 2013. Genetics of tan spot resistance in wheat. Theor. Appl. Genet. 126:2197-2217.

Faris, J. D., Zhang, Z., Lu, H., Lu, S., Reddy, L., Cloutier, S., Fellers, J. P., Meinhardt, S. W., Rasmussen, J. B., Xu, S. S., and Oliver, R. P. 2010. A unique wheat disease resistance-like gene governs effector-triggered susceptibility to necrotrophic pathogens. Proc. Natl. Acad. Sci. 107: 13544-13549.

Felsenstein, J. 2005. PHYLIP version 3.6. Software package. Department of Genome Sciences, University of Washington, Seattle, USA.

Fernandez, M. R., Stevenson, C. F., Hodge, K., Dokken-Bouchard, F., Pearse, P. G., Waelchli, F., Brown, A., and Peluola, C. 2016. Assessing effects of climatic change, region and agronomic practices on leaf spotting of bread and durum wheat in the western Canadian prairies, from 2001 to 2012. Agron. J. 108:1180-1195.

Friedrich, T., Derpsch, R., and Kassam, A. 2012. Overview of the Global Spread of Conservation Agriculture. Field Actions Science Reports [Online], Special Issue 6. http://journals.openedition.org/factsreports/1941

Friesen, T., Holmes, D., Bowden, R., and Faris, J. 2018. ToxA is present in the US Bipolaris sorokiniana population and is a significant virulence factor on wheat harboring Tsn1. Plant Dis. 102:2446-2452.

Friesen, T. L., and Faris, J. D. 2012. Characterization of plant-fungal interactions involving necrotrophic effector-producing plant pathogens. Pages 191-207 in: Plant Fungal Pathogens. Methods in Molecular Biology (Methods and Protocols). M. Bolton and B. Thomma, eds. Humana Press, New Jersey.

Friesen, T. L., Meinhardt, S. W., and Faris, J. D. 2007. The Stagonospora nodorum-wheat pathosystem involves multiple proteinaceous host-selective toxins and corresponding host sensitivity genes that interact in an inverse gene-for-gene manner. Plant J. 51:681-692.

Friesen, T. L., Stukenbrock, E. H., Liu, Z., Meinhardt, S., Ling, H., Faris, J. D., Rasmussen, J. B., Solomon, P. S., McDonald, B. A., and Oliver, R. P. 2006. Emergence of a new disease as a result of interspecific virulence gene transfer. Nat. Genet. 38:953-956.

Gao, Y., Faris, J. D., Liu, Z., Kim, Y. M., Syme, R. A., Oliver, R. P., Xu, S. S., and Friesen, T. L. 2015. Identification and characterization of the SnTox6-Snn6 interaction in the Parastagonospora nodorum-wheat pathosystem. Mol. Plant-Microbe Interact. 28:615-625.

Ghaderi, F., Sharifnabi, B., Javan-Nikkhah, M., Brunner, P., and McDonald, B. A. 2020. SnToxA, SnTox1 and SnTox3 originated in Parastagonospora nodorum in the Fertile Crescent. bioRxiv 202.03.11.987214. https://doi.org/ 10.1101/2020.03.11.987214

Grandaubert, J., Dutheil, J. Y., and Stukenbrock, E. H. 2019. The genomic determinants of adaptive evolution in a fungal pathogen. Evol. Lett. 3: 299-312.

Henriquez, M., Derksen, H., Doherty, J., Miranda, D., and Gruenke, O. 2019. Leaf spot diseases of spring wheat in Manitoba in 2018. Can. J. Plant Pathol. 41:99.

Jansen, C., Von Wettstein, D., Schäfer, W., Kogel, K. H., Felk, A., and Maier, F. J. 2005. Infection patterns in barley and wheat spikes inoculated with wild-type and trichodiene synthase gene disrupted Fusarium graminearum. Proc. Natl. Acad. Sci. 102:16892-16897.

Johnson, T. 1947. A form of Leptosphaeria avenaria on wheat in Canada. Can. J. Res. 25:259-270.

Kamel, S., Cherif, M., Hafez, M., Despins, T., and Aboukhaddour, R. 2019. Pyrenophora tritici-repentis in Tunisia: race structure and effector genes. Front. Plant Sci. 10:1562.
Lamari, L., McCallum, B. D., and Depauw, R. M. 2005. Forensic pathology of Canadian bread wheat: The case of tan spot. Phytopathology 95:144-152.

Leigh, J. W., and Bryant, D. 2015. popart: Full-feature software for haplotype network construction. Methods Ecol. Evol. 6:1110-1116.

Letunic, I., and Bork, P. 2016. Interactive tree of life (iTOL) v3: An online tool for the display and annotation of phylogenetic and other trees. Nucleic Acids Res. 44:W242-W245.

Librado, P. and Rozas, J. 2009. DnaSP v5: A software for comprehensive analysis of DNA polymorphism data. Bioinformatics 25:1451-1452.

Liu, Z., Faris, J., Meinhardt, S., Ali, S., Rasmussen, J., and Friesen, T. 2004a. Genetic and physical mapping of a gene conditioning sensitivity in wheat to a partially purified host-selective toxin produced by Stagonospora nodorum. Phytopathology 94:1056-1060.

Liu, Z., Friesen, T., Rasmussen, J., Ali, S., Meinhardt, S., and Faris, J. 2004b. Quantitative trait loci analysis and mapping of seedling resistance to Stagonospora nodorum leaf blotch in wheat. Phytopathology 94:1061-1067.

Liu, Z., Zhang, Z., Faris, J. D., Oliver, R. P., Syme, R., McDonald, M. C., McDonald, B. A., Solomon, P. S., Lu, S., Shelver, W. L., and Xu, S. 2012. The cysteine rich necrotrophic effector SnToxl produced by Stagonospora nodorum triggers susceptibility of wheat lines harboring Snn1. PLoS Pathog 8:e1002467.

Lu, S., Turgeon, B. G., and Edwards, M. C. 2015. A ToxA-like protein from Cochliobolus heterostrophus induces light-dependent leaf necrosis and acts as a virulence factor with host selectivity on maize. Fungal Genet. Biol. 81: $12-24$.

Manning, V. A., Hardison, L. K., and Ciuffetti, L. M., 2007. Ptr ToxA interacts with a chloroplast-localized protein. Mol. Plant-Microbe Interact. 20:168-177.

Martin, S. I., and Cooke, B. 1979. Effect of wheat and barley hosts on pathogenicity and cultural behaviour of barley and wheat isolates of Septoria nodorum. Trans. Br. Mycol. Soc. 72:219-224.

McCallum, B. D., and DePauw, R. M. 2008. A review of wheat cultivars grown in the Canadian prairies. Can. J. Plant Sci. 88:649-677.

McDonald, M. C., Ahren, D., Simpfendorfer, S., Milgate, A., and Solomon, P. S. 2018. The discovery of the virulence gene ToxA in the wheat and barley pathogen Bipolaris sorokiniana. Mol. Plant Pathol. 19:432-439.

McDonald, M. C., Oliver, R. P., Friesen, T. L., Brunner, P. C., and McDonald, B. A. 2013. Global diversity and distribution of three necrotrophic effectors in Phaeosphaeria nodorum and related species. New Phytol. 199:241-251.

McDonald, M. C., Razavi, M., Friesen, T. L., Brunner, P. C., and McDonald, B. A. 2012. Phylogenetic and population genetic analyses of Phaeosphaeria nodorum and its close relatives indicate cryptic species and an origin in the Fertile Crescent. Fungal Genet. Biol. 49:882-895.

Miller, J. D., and Ewen, M. A. 1997. Toxic effects of deoxynivalenol on ribosomes and tissues of the spring wheat cultivars Frontana and Casavant. Nat. Toxins 5:234-237.

Navathe, S., Yadav, P. S., Chand, R., Mishra, V. K., Vasistha, N. K., Meher, P. K., Joshi, A. K., and Gupta, P. K. 2020. ToxA-Tsn1 interaction for spot blotch susceptibility in Indian wheat: An example of inverse gene-for-gene relationship. Plant Dis. 104:71-81.

Nicholas, K. B. 1997. GeneDoc: Analysis and visualization of genetic variation. EMBNEW NEWS 4:14

O’Donnell, K., and Cigelnik, E. 1997. Two divergent intragenomic rDNA ITS2 types within a monophyletic lineage of the fungusFusariumare nonorthologous. Mol. Phylogenet. Evol. 7:103-116.

Reddy, L., Friesen, T. L., Meinhardt, S. W., Chao, S., and Faris, J. D. 2008. Genomic analysis of the Snn1 locus on wheat chromosome arm 1BS and the identification of candidate genes. Plant Genome 1:55-66.

Richards, J. K., Stukenbrock, E. H., Carpenter, J., Liu, Z., Cowger, C., Faris, J. D., and Friesen, T. L. 2019. Local adaptation drives the diversification of effectors in the fungal wheat pathogen Parastagonospora nodorum in the United States. PLoS Genet. 15:e1008223.

Rizzo, A. F., Atroshi, F., Ahotupa, M., Sankari, S., and Elovaara, E. 1994. Protective effect of antioxidants against free radical-mediated lipid peroxidation induced by DON or T-2 toxin. J. Vet. Med. 41:81-90.

Sarma, G. N., Manning, V. A., Ciuffetti, L. M., and Karplus, P. A. 2005. Structure of $P$. tritici-repentis ToxA: An RGD-containing host-selective toxin from Pyrenophora tritici-repentis. Plant Cell 17:3190-3202.

Shah, D., Bergstrom, G., and Ueng, P. 1995. Initiation of Septoria nodorum blotch epidemics in winter wheat by seedborne Stagonospora nodorum. Phytopathology 85:452-457.

Shaw, D. E. 1957a. Studies on Leptosphaeria avenaria f. sp. avenaria. Can. J. Bot. 35:97-112.

Shaw, D. E. 1957b. Studies on Leptosphaeria avenaria f. sp. triticea on cereals and grasses. Can. J. Bot. 35:113-118.

Shipton, W., Boyd, W., Rosielle, A., and Shearer, B. 1971. The common Septoria diseases of wheat. Bot. Rev. 37:231-262.

Solomon, P. S., Lowe, R. G., Tan, K. C., Waters, O. D., and Oliver, R. P. 2006. Stagonospora nodorum: Cause of Stagonospora nodorum blotch of wheat. Mol. Plant Pathol. 7:147-156. 
Stukenbrock, E. H., and McDonald, B. A. 2007. Geographical variation and positive diversifying selection in the host-specific toxin SnToxA. Mol. Plant Pathol. 8:321-332.

Tan, K. C., Ferguson-Hunt, M., Rybak, K., Waters, O. D., Stanley, W. A., Bond, C. S., Stukenbrock, E. H., Friesen, T. L., Faris, J. D., McDonald, B. A., and Oliver, R. P. 2012. Quantitative variation in effector activity of ToxA isoforms from Stagonospora nodorum and Pyrenophora triticirepentis. Mol. Plant-Microbe Interact. 25:515-522.

Templeton, A. R., Crandall, K. A., and Sing, C. F. 1992. A cladistic analysis of phenotypic associations with haplotypes inferred from restriction endonuclease mapping and DNA sequence data. III. Cladogram estimation. Genetics 132:619-633.

Thompson, J. D., Gibson, T. J., Plewniak, F., Jeanmougin, F., and Higgins, D. G. 1997. The CLUSTAL X windows interface: Flexible strategies for multiple sequence alignment aided by quality analysis tools. Nucleic Acids Res. 25:4876-4882.

Tran, V. A., Aboukhaddour, R., Strelkov, I. S., Bouras, N., Spaner, D., and Strelkov, S. E. 2017. The sensitivity of Canadian wheat genotypes to the necrotrophic effectors produced by Pyrenophora tritici-repentis. Can. J. Plant Pathol. 39:149-162.

Ueng, P., Bergstrom, G., Slay, R., Geiger, E., Shaner, G., and Scharen, A. 1992. Restriction fragment length polymorphisms in the wheat glume blotch fungus, Phaeosphaeria nodorum. Phytopathology 82:1302-1305.
Ueng, P. P., and Chen, W. 1994. Genetic differentiation between Phaeosphaeria nodorum and $P$. avenaria using restriction fragment length polymorphisms. Phytopathology 84:800-806.

Ueng, P. P., Cunfer, B. M., Alano, A. S., Youmans, J. D., and Chen, W. 1995. Correlation between molecular and biological characters in identifying the wheat and barley biotypes of Stagonospora nodorum. Phytopathology 85:44-52.

Vincze, T., Posfai, J., and Roberts, R. J. 2003. NEBcutter: A program to cleave DNA with restriction enzymes. Nucleic Acids Res. 31:3688-3691.

Wheeler, D. L., Barrett, T., Benson, D. A., Bryant, S. H., Canese, K., Chetvernin, V., Church, D. M., DiCuccio, M., Edgar, R., Federhen, S., and Feolo, M. 2007. Database resources of the national center for biotechnology information. Nucleic Acids Res.: D13-D21.

White, T.J., Bruns, T., Lee, S. and Taylor, J. 1990. Amplification and direct sequencing of fungal ribosomal RNA genes for phylogenetics. PCR protocols: A guide to methods and applications 18:315-322.

Winter, M., Samuels, P. L., Dong, Y., and Dill-Macky, R. 2019. Trichothecene production is detrimental to early root colonization by Fusarium culmorum and F. graminearum in Fusarium crown and root rot of wheat. Plant Pathol. 68:185-195

Zhang, Z., Friesen, T. L., Xu, S. S., Shi, G., Liu, Z., Rasmussen, J. B., and Faris, J. D. 2011. Two putatively homoeologous wheat genes mediate recognition of SnTox3 to confer effector-triggered susceptibility to Stagonospora nodorum. Plant J. 65:27-38. 